\title{
Trends in Metal-Based Composite Biomaterials for Hard Tissue Applications
}

\author{
GARGI SHANKAR NAYAK, ${ }^{1}$ ADELE CARRADÒ,${ }^{2}$ PATRICK MASSON,${ }^{2}$ \\ GENEVIËVE POURROY, ${ }^{2}$ FLAVIEN MOUILLARD ${ }^{2}$ \\ VÉRONIQUE MIGONNEY, ${ }^{3}$ CÉLINE FALENTIN-DAUDRE, ${ }^{3}$ \\ CAROLINE PEREIRA, ${ }^{3}$ and HEINZ PALKOWSKI (i) ${ }^{1,4}$,
}

1.-Clausthal University of Technology, Institute of Metallurgy (IMET), Robert-Koch-Straße 42, 38678 Clausthal-Zellerfeld, Germany. 2.-Université de Strasbourg, CNRS UMR 7504, Institut de Physique et Chimie des Matériaux de Strasbourg (IPCMS), 23 rue du Loess BP 43, 67034 Strasbourg, France. 3.-Université Paris 13, CNRS UMR 7244, LBPS/CSPBAT, Sorbonne Paris Cité, 99 Avenue JB Clement, 93340 Villetaneuse, France. 4.-e-mail: heinz.palkowski@tuclausthal.de

The world of biomaterials has been continuously evolving. Where in the past only mono-material implants were used, the growth in technology and collaboration between researchers from different sectors has led to a tremendous improvement in implant industry. Nowadays, composite materials are one of the leading research areas for biomedical applications. When we look toward hard tissue applications, metal-based composites seem to be desirable candidates. Metals provide the mechanical and physical properties needed for loadbearing applications, which when merged with beneficial properties of bioceramics/polymers can help in the creation of remarkable bioactive as well biodegradable implants. Keeping this in mind, this review will focus on various production routes of metal-based composite materials for hard tissue applications. Where possible, the pros and cons of the techniques have been provided.

\begin{tabular}{ll} 
& \multicolumn{1}{c}{ Abbreviations } \\
ATRP & Atom transfer radical polymerization \\
BMGs & Bulk metallic glasses \\
BPF & Bisphenol F epoxy resin \\
CaP & Calcium phosphate \\
CF & Carbon fiber \\
CPC & Calcium phosphate cement \\
CRP & Controlled radical polymerization \\
CVD & Chemical vapor deposition \\
DAEA & 2-Dimethylamino ethyl acrylate \\
ECAE & Equal channel angular extrusion \\
HAp & Hydroxyapatite \\
HDPE & High-density polyethylene \\
HEMA & Hydroxyethyl methacrylate \\
MBE & Molecular beam epitaxy \\
MMCs & Metal matrix composites \\
MS & Magnetron sputtering \\
MSC & Mesenchymal stem cell \\
NMP & N-Methyl-2-pyrrolidone \\
PA & Polyamide
\end{tabular}

(Received August 25, 2021; accepted October 19, 2021;

Published online December 9, 2021)

$\begin{array}{ll}\text { PAA } & \text { Polyacrylic acid } \\ \text { PAM } & \text { Polyacrylamide } \\ \text { PCL } & \text { Polycaprolactone } \\ \text { PDMS } & \text { Polydimethylsiloxane } \\ \text { PEEK } & \text { Polyether ether ketone } \\ \text { PE } & \text { Polyethylene } \\ \text { PEMs } & \text { Polyelectrolyte multilayers } \\ \text { PGA } & \text { Polyglycolic acid } \\ \text { PHBV } & \text { Poly 3-hydroxybutyrate-co-3- } \\ & \text { Hydroxyvalerate } \\ \text { PHEMA } & \text { Poly 2-hydroxyethylmethacrylate } \\ \text { PLA } & \text { Polylactic acid } \\ \text { PLAGA } & \text { Polylactide-co-glycolide } \\ \text { PLD } & \text { Pulsed laser deposition } \\ \text { PLGA } & \text { Polylactic acid-co-glycolic acid } \\ \text { PMMA } & \text { Polymethylmethacrylate } \\ \text { PolyNaSS } & \text { Poly sodium styrenesulfonate } \\ \text { PP } & \text { Polypropylene } \\ \text { PPF } & \text { Polypropylene fumarate } \\ \text { PPHOS } & \text { Poly[(glycine ethyl glycinato)1 } \\ & \text { (phenylphenoxy)1 phosphazene] } \\ \text { pSBMA } & \text { Poly sulfobetaine methacrylate } \\ \text { PSZ } & \text { Partially stabilized zirconia }\end{array}$




\begin{tabular}{|c|c|}
\hline PTEA & Pentaerythritol triacrylate \\
\hline PTFE & Polytetrafluoroethylene \\
\hline PU & Polyurethane \\
\hline PVD & Physical vapor deposition \\
\hline RAFT & $\begin{array}{l}\text { Reversible addition-fragmentation } \\
\text { chain transfer }\end{array}$ \\
\hline RoM & Rule of mixture \\
\hline SI-ATRP & $\begin{array}{l}\text { Surface-initiated atom transfer radical } \\
\text { polymerization }\end{array}$ \\
\hline SLM & Selective laser melting \\
\hline sPGF & Short phosphate glass fibers \\
\hline TCP & Tricalcium phosphate \\
\hline UHMWPE & $\begin{array}{l}\text { Ultra-high molecular weight } \\
\text { polyethylene }\end{array}$ \\
\hline $\mathrm{P}_{\mathrm{s}}$ & Jacuum plasma spraying \\
\hline
\end{tabular}

\section{INTRODUCTION}

Biomaterials, in general terms, are defined as natural or synthetic materials that can be used to augment or replace the biological structure in partial or full capacity to improve the life quality and longevity of an individual. ${ }^{1}$ Early applications of biomaterials can be dated back to ancient civilizations. Historians suggest that the early Romans used to apply glass to recover eye injuries, Chinese and Aztecs utilized the noble nature of gold in dentistry, and Egyptians and Indians used linen as a suture to seal wounds. ${ }^{2}$ Eventually, the growing clinical need and the collaborative effort of material scientists, biologists and chemists led to a tremendous improvement in the material and application range of such materials. Nowadays, biomaterials are used in a variety of body parts. A brief overview and description are shown in Fig. 1.

Given the complexity of the human body, it is always a challenge to fulfill all the necessary requirements for a foreign material to perform as well as the native organs. Just to provide an overview about the challenges, it should be noted that the $\mathrm{pH}$ varies from 1 to 9 in body fluids of various tissues. ${ }^{12}$ Additionally, the mechanics of the body helps to generate massive force concentrations in several body parts, which can vary to a large extent, depending on the individual. In day-to-day life, bones are subjected to maximum stress up to $\sim 4 \mathrm{MPa}$, whereas tendons and ligament stresses are around $40 \mathrm{MPa}$ to $80 \mathrm{MPa}$. The mean load subjected to hip joints can be up to $\sim 3 \mathrm{kN}$, which increases up to tenfold during jumping. Another crucial point is the fluctuation and repetition of these stresses depending on the activity such as sitting, standing, stretching, climbing, jogging and running. ${ }^{13}$ Even if a material can fulfill the structural compatibility desired, it still must also be biocompatible to interact with the human tissue without any negative effects such as inflammation or creation of undesirable chemical components. Biocompatibility can be defined as the ability of the material to show favorable response in a given biological environment without having any risk of rejection by the immune system, toxicity, injury or any other undesirable effect. ${ }^{14-16}$

As it has not yet been possible for a single material to fulfill all the above-mentioned requirements, the biomaterials are classified based on the structural and biocompatibility to allocate them in

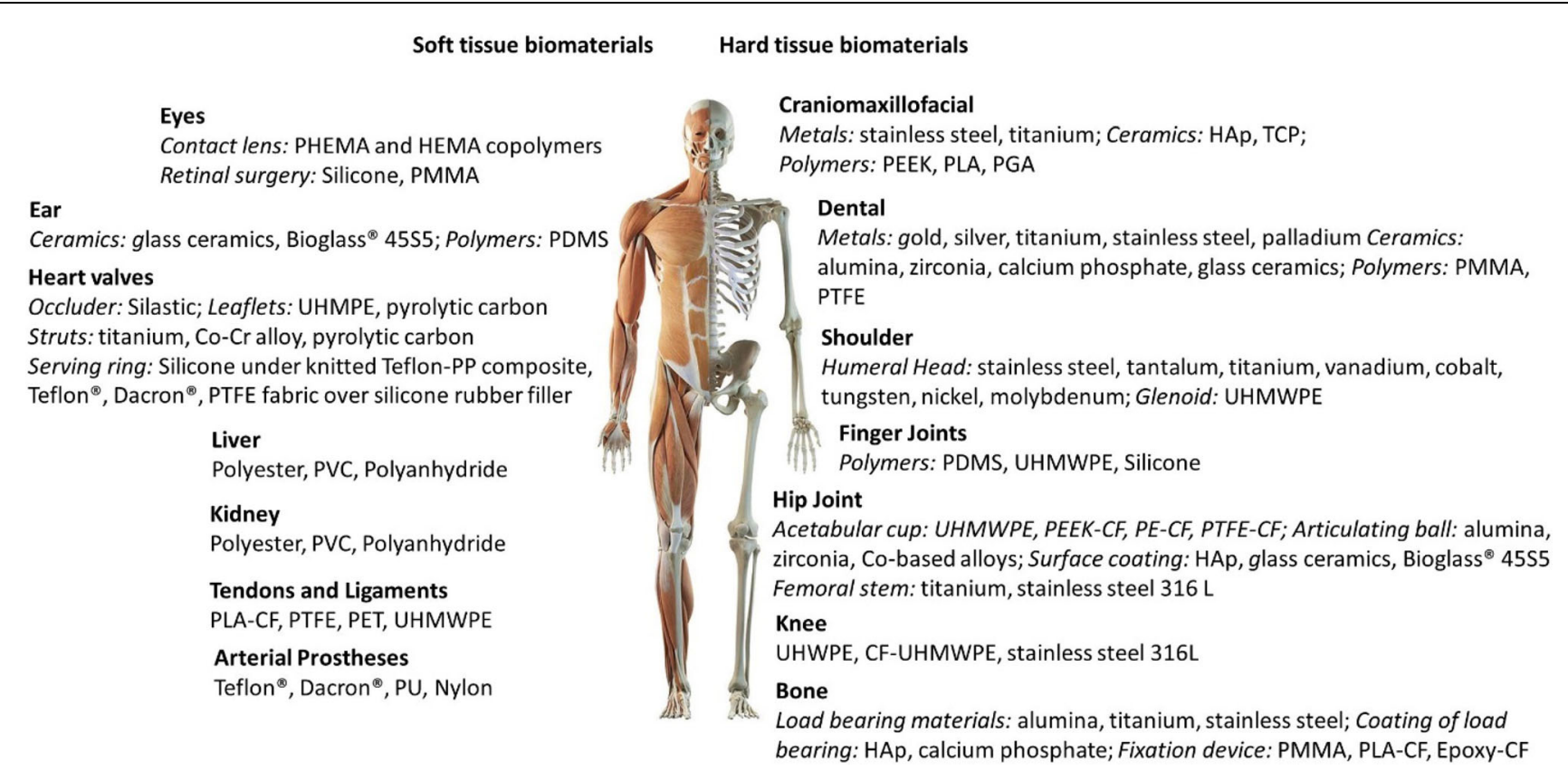

Fig. 1. Hard and soft tissue biomaterials applied to the human body. ${ }^{3-11}$ 
applications according to their properties. The structural compatibility difference divides biomaterials into (1) natural materials, (2) metals, (3) ceramics, (4) polymers and (5) composites, which are developed by different combinations of the above. ${ }^{17,18}$ Whereas, the biocompatibility difference divides biomaterials into (1) bioinert [e.g., titanium (Ti) and its alloys, some steel grades, alumina $\left(\mathrm{Al}_{2} \mathrm{O}_{3}\right)$, titanium nitride $\left(\mathrm{Ti}_{x} \mathrm{~N}_{y}\right)$, titanium dioxide $\left(\mathrm{TiO}_{2}\right)$, zirconia $\left(\mathrm{ZrO}_{2}\right)$ ], (2) bioactive [e.g., hydroxyapatite (HAp), $\mathrm{Ca}_{10}\left(\mathrm{PO}_{4}\right)_{6}(\mathrm{OH})_{2}$, bioactive glasses (e.g., $\mathrm{CaO}-\mathrm{SiO}_{2}-\mathrm{P}_{2} \mathrm{O}_{5}-\mathrm{Na}_{2} \mathrm{O}$ ) and glass ceramics $]^{19-21}$ and (3) bioresorbable [e.g., tricalcium phosphate (TCP), $\mathrm{Ca}_{3}\left(\mathrm{PO}_{4}\right)_{2}$, some alloys of magnesium $(\mathrm{Mg})$, zinc $(\mathrm{Zn})$ and iron $(\mathrm{Fe}){ }^{19,22}$ The bioinert materials are the least biocompatible, which show minimum interactions with surrounding tissues after being placed inside the body. Bioactive and bioresorbable materials interact with surrounding tissues to a high extent with no harmful effects, where bioresorbable materials even get resorbed by the hydrolytic breakdown in the body and slowly get replaced by the advancing tissue (e.g., bone). The chemical by-products during this process are absorbed and released by the body via various metabolic processes. $^{23,24}$ The challenge-among others-is to adapt the corrosion of the implanted material to the growth of the tissue.

Biomaterials are primarily used to replace hard and soft tissues that have been damaged or destroyed. ${ }^{25}$ As the mechanical properties required for hard tissues are quite high compared to soft tissues, the material selection for such applications also varies to a high extent. ${ }^{12,26}$ In Table I, some mechanical properties of hard tissues and different classes of biomaterials along with their respective biocompatibility for hard tissue applications are listed.

The biocompatibility of natural biomaterials is evidently the highest, but their lack of mechanical strength renders them unsuitable for hard tissue applications. ${ }^{17,80}$ The high elastic modulus and tensile strength provide metals and alloys a better load-bearing capacity and thus are being widely used for hard tissue applications. ${ }^{81,82}$ However, their bioinertness (excluding $\mathrm{Mg}, \mathrm{Fe}, \mathrm{Zn}$ ), corrosion and stress shielding phenomena are major areas of concern. ${ }^{83-85}$ Bioceramics, in general, have better compatibility due to their corrosion resistance but their high yield modulus, brittleness and poor workability hinder their efficacy. ${ }^{86,87}$ In the case of polymeric biomaterials, biocompatibility and processability could be considered their strength and poor degradability, difficulties in sterilization and structural instability as their weakness. ${ }^{80,88}$

Composite biomaterials have been shown to minimize the limitations of other types of biomaterials along with enhancing their benign aspects. ${ }^{35,38,48,57,72,74,89-93]}$ For hard tissue applications, metallic biomaterials are preferable candidates due to their desirable mechanical properties, which on one hand can compensate for the poor mechanical properties of the additives (ceramics or polymers) and, on the other, provide ease of production for bioactive/biodegradable composites with properties similar to bones. ${ }^{94}$ For example, even though HAp is biodegradable, it does not have the necessary compressive strength to be used for loadbearing applications. In this case, the addition of $\mathrm{Ti}$ to HAp would not only provide the necessary strength but would also provide bioactivity to the prepared implant. ${ }^{83}$ Similarly, even though magnesium is a desirable candidate for biodegradable implants, the fast corrosion of $\mathrm{Mg}$ causes the implant to fail before the bone heals. ${ }^{95}$ In this case, addition of polymer or ceramic reinforcements can be helpful in controlling the degradation rate and achieving biocompatible corrosion products. ${ }^{96,97}$

In the following sections, different synthesis routes of metal-based composite biomaterials for hard tissue applications have been illustrated.

\section{FABRICATION ROUTES OF METAL-BASED COMPOSITE BIOMATERIALS}

Fabrication of composite biomaterials varies according to the matrix and reinforcement. Thus, in this section, the classification for the fabrication route is based on various combinations of metals, polymers and ceramics.

\section{Surface Functionalization}

The biggest problems with metallic biomaterials are their bioinertness (for Ti- and stainless-steelbased implants) and corrosive properties (for Mgand $\mathrm{Zn}$-based implants). In recent years, several techniques have been developed to make the surface bioactive and corrosion resistant by attaching bioactive ceramics and polymers. ${ }^{98-103}$ As shown in Table II, there are various techniques that can be applied for coating, depending on the desired material to be deposited, coating strength required and investment costs.

\section{Dry Coating Techniques}

Various deposition techniques are developed to obtain thin films. Some are based on chemical processes such as chemical vapor deposition (CVD) and molecular beam epitaxy (MBE), and others use physical routes: magnetron sputtering (MS) and pulsed laser deposition (PLD). Due to its numerous advantages, the latter is widely used in surface engineering, for instance, in microelectronics and biomedical applications, and allows easy production of functional coatings. ${ }^{104}$

These coating methods rely on the high energy provided by the system to achieve fast deposition via melting/vaporization and solidification and/or accelerated flow of particles toward the metallic substrate surfaces. ${ }^{105}$ These techniques are mostly popular for coating of ceramics in industrial 
Table I. Classification of biomaterials based on structural and biocompatibility

\begin{tabular}{|c|c|c|c|c|}
\hline Materials & $\begin{array}{c}\text { Young's } \\
\text { modulus (GPa) }\end{array}$ & Tensile strength (MPa) & Biocompatibility & References \\
\hline \multicolumn{5}{|l|}{ Human tissue } \\
\hline Cortical bone & $3.9-20$ & $52-133$ & N/A & $12,27-29$ \\
\hline Trabecular bone & $0.14-0.5$ & $1-7.4$ & N/A & $12,30,31$ \\
\hline Enamel & $97.2-102.6$ & 10 & N/A & 32,33 \\
\hline Dentin & $19.2-20.5$ & $34.5-52$ & N/A & 33,34 \\
\hline \multicolumn{5}{|l|}{ Natural biomaterials } \\
\hline Cellulose & $24.3-37.5$ & $492.6-543.1$ & Biodegradable & 35 \\
\hline Collagen & $0.0018-0.046$ & $0.9-7.4$ & Biodegradable & 36 \\
\hline Silk fibroin & $15-17$ & 740 & Biodegradable & 37 \\
\hline Chitosan & 1.609 & 40.37 & Biodegradable & 38 \\
\hline Alginate & 1.4 & 5.27 & Biodegradable & 39 \\
\hline \multicolumn{5}{|l|}{ Metallic biomaterials } \\
\hline CP Ti (grade 1-4) & 100 & $240-550$ & Bioinert & 40,41 \\
\hline Ti-5Al-2.5Fe & 110 & 1020 & Bioinert & 41 \\
\hline Ti-6Al-4V & 109 & 1110 & Bioinert & 42 \\
\hline Ti-13Nb-13Zr & $79-84$ & 973-1037 & Bioinert & 41 \\
\hline Ti-12Mo-6Zr-2Fe & $74-85$ & $1060-1100$ & Bioinert & 41 \\
\hline Ti-35Nb-4Sn-6Mo-9Zr & 65 & 834 & Bioinert & 43 \\
\hline $\mathrm{Ti}-35 \mathrm{Nb}-7 \mathrm{Zr}-5 \mathrm{Ta}$ & 55 & 596 & Bioinert & 41 \\
\hline $\mathrm{NiTi}$ & $\begin{array}{c}E_{\mathrm{A}}=83, E_{\mathrm{M}}=28- \\
41\end{array}$ & $\begin{array}{l}U T S_{\mathrm{A}}=640-1380 \\
U T S_{\mathrm{M}}=103-862\end{array}$ & Bioinert & $27,41,44$ \\
\hline SS 316L & 193 & 490 & Bioinert & 45 \\
\hline Co-Cr-W-Ni & 210 & 860 & Bioinert & 46 \\
\hline Co-Ni-Cr-Mo & 232 & 793 & Bioinert & 46 \\
\hline Co-Cr-Mo & 240 & 725 & Bioinert & 47,48 \\
\hline Tantalum (annealed) & 185 & 207 & Bioinert & 49 \\
\hline Pure iron & 200 & 210 & Biodegradable & 46 \\
\hline $\mathrm{Fe}-35 \mathrm{Mn}$ & 179 & 550 & Biodegradable & 50 \\
\hline Pure magnesium & 44 & 160 & Biodegradable & 49,51 \\
\hline Mg-based alloy WE43 & 44 & 250 & Biodegradable & 46 \\
\hline Mg-based alloy AZ31 & 40.2 & 260 & Biodegradable & 52,53 \\
\hline Mg-Zn-Ca BMGs & $22-50$ & $300-500$ & Biodegradable & 54 \\
\hline \multicolumn{5}{|l|}{ Ceramic biomaterials } \\
\hline Alumina & $380-420$ & $282-551$ & Bioinert & 19 \\
\hline Zirconia & 210 & $800-1500$ & Bioinert & 55 \\
\hline Silicon nitride & 304 & $700-1000$ & Bioinert & 55 \\
\hline HAp & $115-120$ & $80-110$ & Biodegradable & 56 \\
\hline CPC & $\sim 2.5$ & 4 (Flexural) & Biodegradable & 57 \\
\hline Bioglass $® ~(45 S 5)$ & 35 & 42 & Bioactive & 58 \\
\hline Glass ceramics & 30 & 200 (bending) & Bioactive & 59 \\
\hline \multicolumn{5}{|l|}{ Polymeric biomaterials } \\
\hline PLA & $2 \pm 0.1$ & $66 \pm 4.4$ & Biodegradable & 60 \\
\hline PGA & $\sim 0.2$ (tangent) & 80 (tangent) & Biodegradable & 61 \\
\hline PLGA & $0.06-0.1$ & $2.5-2.6$ & Biodegradable & 62 \\
\hline PCL & $\sim 0.1$ (tangent) & $\sim 25$ & Biodegradable & 61 \\
\hline PPF (annealed) & $3.1 \pm 0.3$ & $111 \pm 2.4$ & Biodegradable & 63 \\
\hline Polyurethane (PU) & $\sim 0.08$ & $\sim 18$ & Biodegradable & 64 \\
\hline $\mathrm{HA}$ & & $2520-2600$ & Biodegradable & 65 \\
\hline PMMA & $3-5$ & $48-76$ & Bioinert & 66 \\
\hline PEEK & $3-4$ & 80 & Bioinert & 66 \\
\hline \multicolumn{5}{|l|}{ Composite biomaterials } \\
\hline CP Ti-2 wt.\% nano HAp (selective & $28.86 \pm 0.3$ & $289.01 \pm 12.3$ & Bioinert & 67 \\
\hline laser melting) & & & & \\
\hline 50Ti-50Hf-BPF & $20.8 \pm 1.3$ & $266 \pm 17$ (yield strength) & Bioinert & 68 \\
\hline $\begin{array}{l}\text { Mg-15 wt.\%HAp (milling and sin- } \\
\text { tering) }\end{array}$ & $52.4 \pm 4.2$ & - & Biodegradable & 69 \\
\hline $\begin{array}{l}\text { Mg-15 wt.\%HAp (casting and } \\
\text { extrusion) }\end{array}$ & - & 136.7 & Biodegradable & 70 \\
\hline
\end{tabular}




\begin{tabular}{|c|c|c|c|c|}
\hline Materials & $\begin{array}{l}\text { Young s modulus } \\
\text { (GPa) }\end{array}$ & $\begin{array}{c}\text { 1ensile strength } \\
\text { (MPa) }\end{array}$ & Biocompatibility & References \\
\hline Mg-30 wt.\%HAp (powder metallurgy) & - & $92.0 \pm 10.8$ & Biodegradable & 71 \\
\hline HDPE- 10 wt. $\% \mathrm{TiO}_{2}-20$ wt. $\% \mathrm{Al}_{2} \mathrm{O}_{3}$ & 0.5 & 16.1 & Bioinert & 72 \\
\hline $\begin{array}{l}\mathrm{HDPE}-20 \mathrm{vol} . \% \mathrm{HAp}-20 \mathrm{vol} . \mathrm{ss} \% \mathrm{Al}_{2} \mathrm{O}_{3} \text { (com- } \\
\text { pression molding) }\end{array}$ & $6.2 \pm 0.9$ & - & Bioactive & 73 \\
\hline PLGA-PCL-CaP (in vitro) & $0.04-0.12$ & - & Biodegradable & 74 \\
\hline PCL-TCP (in vivo) & & & Biodegradable & 75 \\
\hline PPHOS-PLAGA (in vitro) & 0.02 & - & Biodegradable & 76 \\
\hline 30 wt. $\%$ Chitosan-70 wt.\% PLAGA & 0.15 & $1.5 \pm 0.4$ & Biodegradable & 77 \\
\hline $\begin{array}{l}\text { Alginate-CPC-hydrogel umbilical cord } \\
\text { MSC }\end{array}$ & 0.7 & - & Biodegradable & 78 \\
\hline Chitosan-CPC & $\begin{array}{l}0.04 \pm 0.02- \\
2.94 \pm 0.36\end{array}$ & $\begin{array}{l}3.2 \pm 0.6- \\
25.3 \pm 2.9\end{array}$ & Biodegradable & 79 \\
\hline
\end{tabular}

N/A: not applicable, SS 316L: Fe; 0.08C; 2Mn; 0.75Si; 16-18Cr; 10-14Ni; 2-3Mo; 0.045P; 0.03S; 0.1N, Mg WE43: Mg; 3.7-4.3Y; 2.4-4.4Nd; 0.4-1Zr Mg AZ31: Mg; 05.3Al; 02.4Mn; 04.6Zn.

Table II. Classification of surface modification techniques applied for metallic biomaterials

\begin{tabular}{|c|c|c|c|}
\hline \multirow{2}{*}{$\begin{array}{l}\begin{array}{l}\text { Dry coating } \\
\text { techniques }\end{array} \\
\text { Thermal spray- } \\
\text { ing, e.g., HAp } \\
\text { coating on CP Ti } \\
\text { grade } 2^{127}\end{array}$} & \multicolumn{3}{|c|}{ Wet coating techniques } \\
\hline & \multicolumn{2}{|c|}{ Covalent bonding } & Non-covalent bonding \\
\hline $\begin{array}{l}\text { Sputtering } \\
\text { TiSiN coating } \\
\text { on SS316L }\end{array}$ & $\begin{array}{l}\text { Grafting from, e.g., grafting of } \\
\text { pSBMA on Ti-6Al-4V via SI- } \\
A T R P ;^{132} \text { electrografting of PTEA } \\
\text { followed by grafting of DAEA via }\end{array}$ & $\begin{array}{c}\text { Grafting to, e.g., grafting of } \\
\text { PolyNaSS on CP Ti grade } 2 \text { via } \\
R A F T ;{ }^{134} \text { grafting of PEG on SS } \\
304 \text { via } S A M^{135}\end{array}$ & $\begin{array}{c}\text { Electrophoretic deposition, e.g., } \\
\text { deposition of sPGF-PA compos- } \\
\text { ite on stainless-steel sub- } \\
\text { strate }^{136}\end{array}$ \\
\hline$P L D$ & $N M P] ;{ }^{133}$ grafting of polyNaSS on & & Physisorption \\
\hline $\begin{array}{l}\text { HAp coating } \\
\text { on } \mathrm{CP} \mathrm{Ti}^{129}\end{array}$ & CP Ti grade 2 via $U V$ grafting ${ }^{134}$ & & $\begin{array}{c}\text { PAA coating on Ti6Al4V } \\
\text { surface }^{137}\end{array}$ \\
\hline $\begin{array}{l}\text { HIP } \\
\text { HAp coating } \\
\text { on CP } \mathrm{Ti} \\
\operatorname{rod}^{130}\end{array}$ & & & $\begin{array}{l}\text { Sol-gel, e.g., PLA biocomposite } \\
\text { coating on Ti- } 6 \mathrm{Al}-4 \mathrm{~V} \text { discs via } \\
\text { dip coating. }{ }^{138} \text { HAp coating on } \\
\text { SS } 316 \mathrm{~L} \text { via spin coating }{ }^{139,140}\end{array}$ \\
\hline Cold spraying & & & \\
\hline HAp coating on & & & \\
\hline AZ51 alloy ${ }^{131}$ & & & \\
\hline
\end{tabular}

applications. However, recently, these techniques have also been used for biomedical applications. The major advantages and disadvantages of these techniques regarding biomedical applications are shown in Table III.

Thermal spraying is the most widely used technique for coating of bioceramics on metallic biomaterials. Since the late 1980 s, thermal spraying has been a popular technique for coating HAp on metallic biomaterials. ${ }^{106-110}$ This method uses different media such as flame, plasma arc or electric arc to melt the precursor and spray it onto the surface. ${ }^{111,112}$ The mechanism of coating includes substrate penetration and/or particle deformation via impact energy. ${ }^{112}$ The advantages of thermal spraying include rapid deposition and cost-effective coating. ${ }^{113}$ With the growth in technology, several varieties of thermal spraying, such as flame, arc, atmospheric plasma, vacuum plasma, suspension plasma, coupled radiofrequency plasma, high-velocity suspension flame and gas tunnel plasma spraying, etc., have been implemented for biomedical purposes. ${ }^{114-118}$ Thermal spraying has also been used to coat implants with $\mathrm{HAp} / \mathrm{SiO}_{2}$ composites, $\mathrm{HAp} / \mathrm{Ti}$ or dicalcium/ Ti, $\mathrm{Al}_{2} \mathrm{O}_{3}-\mathrm{TiO}_{2}, \mathrm{ZrO}_{2}, 45 \mathrm{~S} 5$ bioglass and more. ${ }^{119-124}$ Thermal sprayed coatings can minimize stress shielding, the major problem in Ti femoral stems used for total hip arthoplasty. ${ }^{125}$ 
Table III. Some advantages and disadvantages of various dry coating techniques

\begin{tabular}{|c|c|c|c|c|}
\hline Technique & Schematic & Advantages & Disadvantages & References \\
\hline $\begin{array}{l}\text { Thermal } \\
\text { spraying }\end{array}$ & 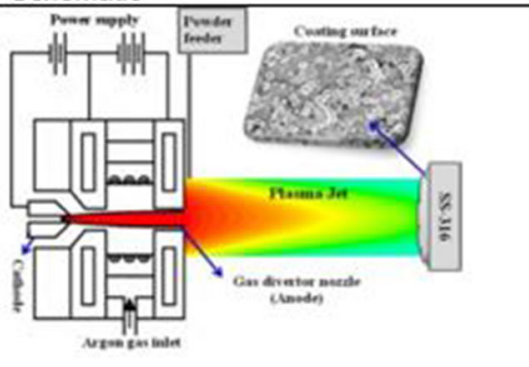 & $\begin{array}{l}\text { High deposition } \\
\text { rate, cost- } \\
\text { effective, coatings } \\
\text { with micro-rough } \\
\text { surfaces }\end{array}$ & $\begin{array}{l}\text { Amorphous } \\
\text { coating, high } \\
\text { temperature } \\
\text { induces } \\
\text { decomposition of } \\
\text { coating, low } \\
\text { porosity, coating } \\
\text { spalling and } \\
\text { interface } \\
\text { separation, line- } \\
\text { of-sight technique }\end{array}$ & $\begin{array}{c}{[113,170,213,2} \\
14]\end{array}$ \\
\hline $\begin{array}{l}\text { Cold } \\
\text { spraying }\end{array}$ & Cos bater & $\begin{array}{l}\text { High deposition } \\
\text { rate, high } \\
\text { deposition } \\
\text { efficiency, dense } \\
\text { coating, low } \\
\text { temperature } \\
\text { depositon }\end{array}$ & $\begin{array}{l}\text { Deformation } \\
\text { induced residual } \\
\text { stress is } \\
\text { detrimental for } \\
\text { thick coating, } \\
\text { substrate required } \\
\text { to have some } \\
\text { ductility, coating } \\
\text { of ceramics is still } \\
\text { a challenge }\end{array}$ & {$[215-217]$} \\
\hline Sputtering & 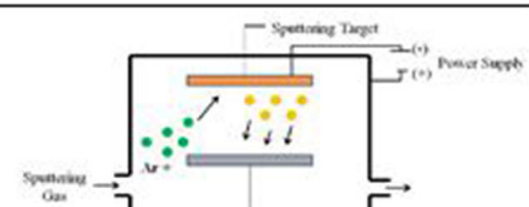 & $\begin{array}{l}\text { Good adhesion } \\
\text { strength, uniform } \\
\text { coating with high } \\
\text { density }\end{array}$ & $\begin{array}{l}\text { Line-of-sight } \\
\text { technique, low } \\
\text { deposition rate, } \\
\text { expensive, } \\
\text { amorphous } \\
\text { coating }\end{array}$ & $\begin{array}{c}{[186,202,218,2} \\
19]\end{array}$ \\
\hline PLD & L & $\begin{array}{l}\text { Dense and } \\
\text { porous coating } \\
\text { with crystalline } \\
\text { and amorphous } \\
\text { phases, ease to } \\
\text { prepare multilayer } \\
\text { coating with } \\
\text { different materials }\end{array}$ & $\begin{array}{l}\text { Line-of-sight } \\
\text { technique, } \\
\text { oxidation } \\
\text { problems due to } \\
\text { high temperature, } \\
\text { lack uniformity }\end{array}$ & {$[111,113,220]$} \\
\hline $\begin{array}{l}\text { Hot } \\
\text { isostatic } \\
\text { pressing }\end{array}$ & 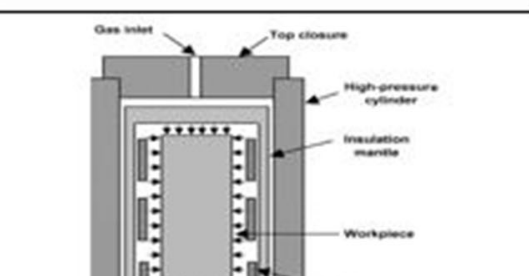 & $\begin{array}{l}\text { Dense coatings, } \\
\text { homogeneous } \\
\text { structure and } \\
\text { uniform coatings, } \\
\text { no dimensional or } \\
\text { shape limitation, } \\
\text { good temperature } \\
\text { control }\end{array}$ & $\begin{array}{l}\text { Complex shaped } \\
\text { substrates cannot } \\
\text { be coated, } \\
\text { expensive, } \\
\text { removal of } \\
\text { encapsulation } \\
\text { material is difficult }\end{array}$ & $\begin{array}{c}{[111,212,221,2} \\
22]\end{array}$ \\
\hline
\end{tabular}

In the table, Fig. 1 is reprinted with permission from Ref. 214; Fig. 2 is reprinted with permission from Ref. 217 ; Fig. 3 is reprinted from an open access journal; ${ }^{218}$ Fig. 4 is reprinted from an open access journal; ${ }^{20}$ Fig. 5 is reprinted with permission from Ref. 222

Currently, the most used biocoatings for implantology are HAp, alumina and titanium nitride. They are frequently coated on $\mathrm{Ti}$ and its alloys as well as 316L stainless-steel or CoCr steel alloys. Recently,
Durairaj et al. have studied the effect of HAp coating via plasma spraying on anticorrosion properties of metallic biomaterial surfaces. ${ }^{126}$ The study was conducted for both SS 316L and Ti6Al4V. A 


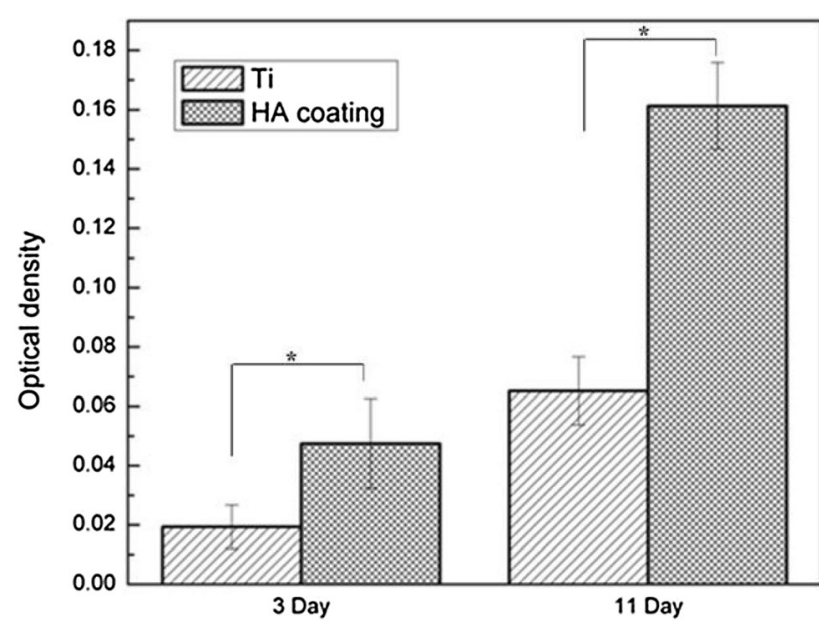

Fig. 2. MTT assay of hFOB cells on Ti- and HAp-coated Ti surfaces as a function of cell culture time. Optical density is directly proportional to the concentration of living cells. A significantly higher concentration of live cells has been found on HAp-coated $\mathrm{Ti}$. *Significant difference in performance. Reprinted with permission from Ref. 141.

better anticorrosion property was found on HApcoated surfaces for both materials. It was found out that the potential required for localized corrosion increases after HAp coating on both surfaces. The corrosion rate for SS316L and Ti6Al4V was found to be $2.703 \mathrm{~mm} /$ year and $0.962 \mathrm{~mm} /$ year, respectively, which decreased to $0.0113 \mathrm{~mm} / \mathrm{year}$ and $0.00801 \mathrm{~mm} /$ year using a HAp coating, respectively.

In another study, in vitro and in vivo response of HAp coatings on commercially pure (CP) $\mathrm{Ti}$ via coupled radio frequency plasma spraying has been investigated. ${ }^{141}$ Human fetal osteoblast cells (hFOB) were used to perform cell culture tests for 3 and 11 days, taking $\mathrm{CP} \mathrm{Ti}$ as reference material. As expected, HAp-coated $\mathrm{Ti}$ showed better cell attachment and differentiation compared to uncoated Ti (see Fig. 2). Implantation of the material in cortical defect of rat femur was used to determine the in vivo biocompatibility. The results suggest a higher osteoid content on the HAp-coated Ti implant surface, which is the precondition for better new bone formation, where no osteoid was found on the uncoated Ti surface even after 14 days of implantation, indicating the absence of cellular activity.

Alumina $\left(\mathrm{Al}_{2} \mathrm{O}_{3}\right)$, which is a polymorphous material, ${ }^{142-144}$ can be deposited by chemical and physical vapor deposition (CVD and PVD). ${ }^{145-149}$ Furthermore, its chemical inertness ${ }^{150}$ under physiological conditions associated with strong wear resistance, and excellent hardness makes it an actractive material in tribological ${ }^{151,152}$ and biomaterial applications. ${ }^{153,154}$ Joint $^{155}$ and hip replacement prostheses ${ }^{156}$ are partly made of $\mathrm{Al}_{2} \mathrm{O}_{3}$. For substituing large sections of bone, for instance to replace cancerous bone, porous alumina is prefered because it acts as a scaffold for a new bone growing into the pores.

Titanium nitride (TiN) coatings are often encountered in industrial applications requiring tribological performances coming out from its high surface hardness ${ }^{157}$ and chemical properties. ${ }^{158}$ Moreover, TiN is well tolerated by the tissues because of its inertness. ${ }^{159}$ Furthermore, when TiN is used as an interlayer between HAp films and bulk $\mathrm{Ti}$, the mechanical performances of HAp films are increased because of the improvment in bonding. ${ }^{160}$ Moreover, $\mathrm{PLD}^{161}$ and $\mathrm{MS}^{160}$ allow producing thin TiN coatings with strong fatigue resistance as well as very strong adherence to the substrate. This results in mechanical properties (e.g., hardness, Young's modulus, stiffness and mechanical wear) similar to those of bone.

Polymer coating on metallic implants has also been achieved via thermal spraying: ${ }^{162-164}$ In an interesting study, Chebbi et al. were able to achieve a poly 3-hydroxybutyrate-co-3-hydroxyvalerate/ polymethylmethacrylate (PHBV/PMMA) and PHBV/PMMA-HAp bi-layer coating on Ti6Al4V implants. ${ }^{107}$ In vitro analysis of the coated samples suggested that the polymers were able to withstand their bioactive functionalities even after coating, opening possibilities for novel polymer coatings on metallic implants via thermal spraying. Unfortunately, not much research has been focussed in this area in recent years. However, in an inspired research, the vaccum plasma spray (VPS) technique has been shown to coat Ti on polyether ether ketone (PEEK) to improve its biocompatibility along with minimizing the stress-shielding phenomenon. ${ }^{165}$ In this study, a highly microporous spongy Ti coating was achieved on PEEK with an isoelastic structure, thus preventing spalling of the coating (see Fig. 3). The in vivo study found a significant improvement in bone recovery by the Ti coating, as the rate of new bone formation was found to be much higher for Ticoated PEEK than for uncoated PEEK (see Fig. 4).This study puts forward a novel path for the preparation of composites for spine implant.

Even though widely used, the high temperature applied in thermal spraying is a major problem. The high temperature converts crystalline HAp to $\alpha \mathrm{TCP}$, $\beta$ TCP, tetra TCP and oxy HAp, which are amorphous in nature. As bone has crystalline HAp, this causes a mismatch between bone and implant, and coated HAp is readily dissolved in blood plasma, causing early instability of the implant and ultimate failure after some time. ${ }^{111,112,166-168}$ In addition, particle size destruction, thermal and residual stresses in the coating, porosity and inhomogenity in the coating are also major causes of concern in using this technique. ${ }^{169,170}$ The mechanical properties of the HAp coating via thermal spraying are also dependent on the thickness of the coating. A study found that a HAp coating of about $150 \mu \mathrm{m}$ via VPS on Ti6Al4V significantly diminished the fatigue strength of the coating, which was not the case 


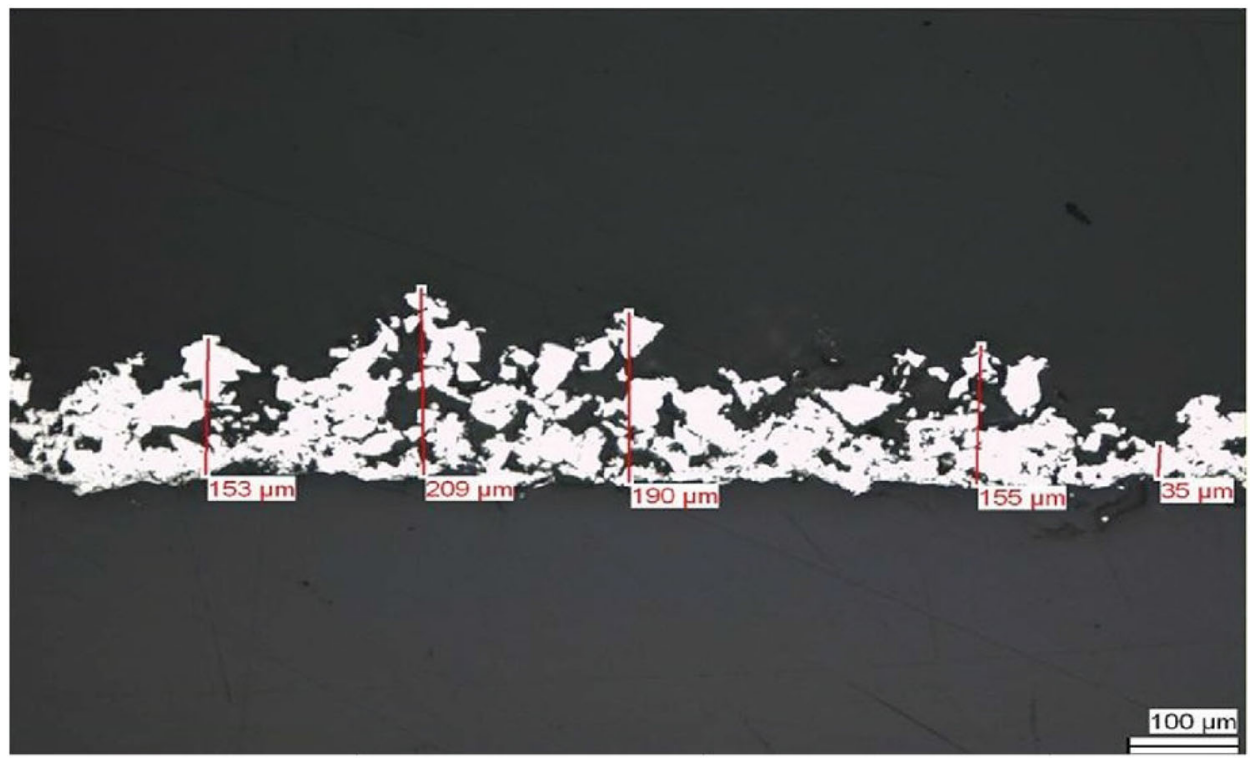

Fig. 3. Optical microscopy of Ti coating on PEEK. A highly microporous network of coating can be seen. Reprinted with permission from Ref. 165.

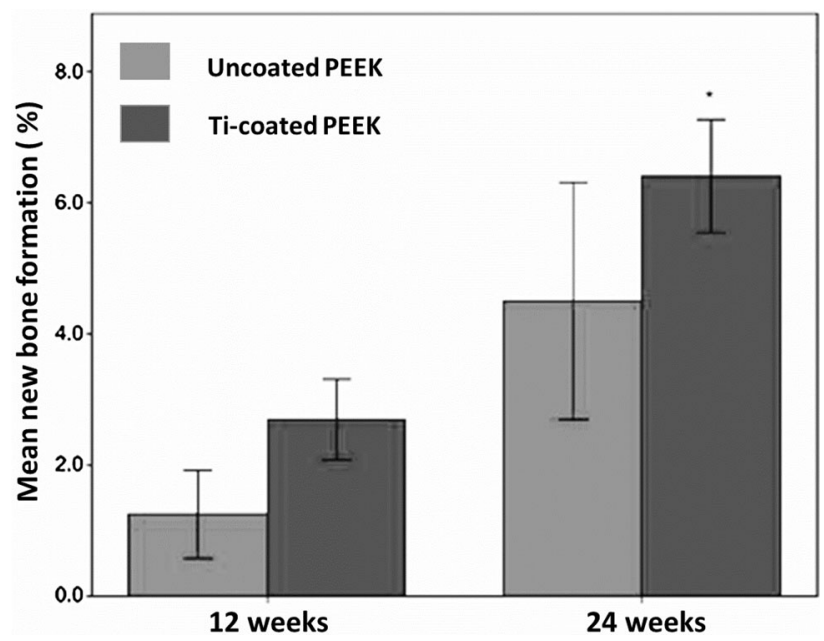

Fig. 4. New bone formation comparison between control (uncoated PEEK) and Ti-coated PEEK. A significant improvement in bone recovery via Ti coating could be seen. Adapted with permission from Ref. 165.

in 25-100- $\mu$ m-thick HAp coatings. ${ }^{171}$ Moreover, thermal spray coating implant devices with HAp on metal substrates showed disadvantages and failure at interface due to the compressive residual stresses occurring during the coating. ${ }^{170}$

To minimize the above-mentioned high-temperature problems, several studies on the application of cold spraying for biomedical applications have also been done. ${ }^{172-175}$ In cold spraying, the particles are heated below its melting temperature and accelerated to very high speed using a carrier gas toward the substrate to achieve adhesion. ${ }^{169}$ It provides an outstanding advantage of room temperature deposition with high deposition efficiency, where the particles can retain their crystal structure even after deposition. ${ }^{169,176}$ Its ease of application has allowed the successful coating of HAp, HAp/Ti, $\mathrm{HAp}-\mathrm{Ag} / \mathrm{PEEK}$ and $\mathrm{HAp} /$ graphene composites on various metallic substrates with intact structural features. . $^{131,177-180}$

In a recent study, the efficiency of cold spraying to coat Ti6Al4V alloys with tantalium (Ta) and its in vitro bioactivity has been investigated. ${ }^{181} \mathrm{~A}$ rough and porous coating of Ta was achieved without oxidation (see Fig. 5), which was able to promote HAp mineralization in SBF solution, resulting in good bioactivity. Literature suggests that rough surface is beneficial for the cell attachment and proliferation. ${ }^{182,183}$ Thus, this study suggests a good path for bioactivation of inert metallic implants.

Other techniques have also been applied for biomedical applications to minimize or mitigate these problems. PVD-based deposition techniques are one of the best alternatives to thermal spraying. Sputtering, PLD, ion beam-assisted deposition, arc ion plating and cathode arc deposition are the most popular PVD-based techniques for biomedical applications. Among these, sputtering is the most commonly used PVD-based technique where coating is achieved by ejecting material from the "target," i.e., the material to be deposited, via ion bombardment. These ejected particles later move toward the substrate and form a coating via condensation in a reactive or inert environment. ${ }^{184}$ This technique allows a better controlled deposition of thin 

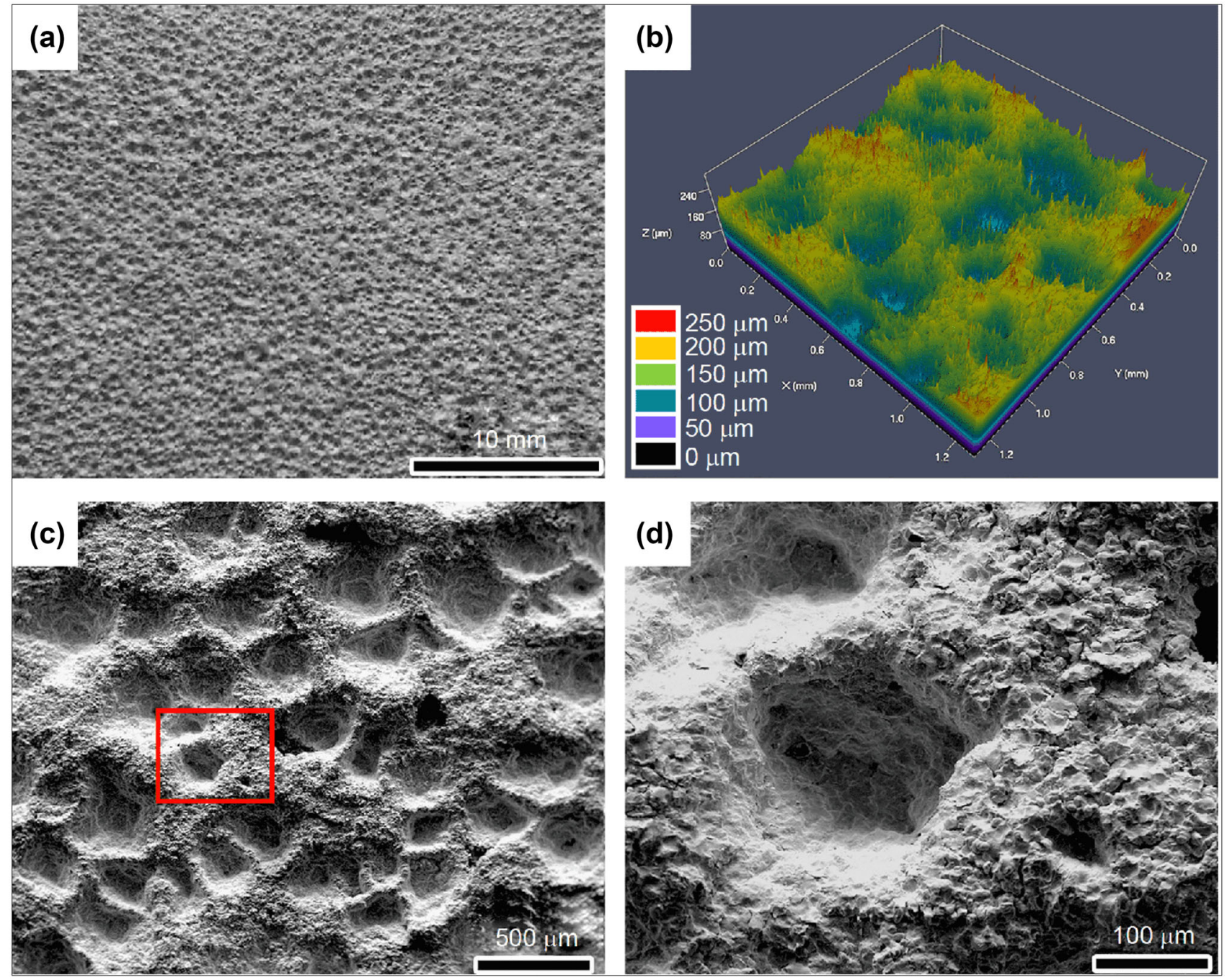

Fig. 5. (a) Macroscopic, (b) laser confocal and (c) and (d) SEM images of the surface morphology of tatalium (Ta) coating via cold spraying. A rough and microporous surface can be seen. Reprinted with permission from Ref. 181.

coatings. ${ }^{185}$ The adhesion strength of coating achieved by sputtering was found to be higher than that of thermal (plasma) spraying, given its cleanliness, enhanced atomic diffusion and mixing at interface as well as better mechanical interlocking. ${ }^{113,186}$ Given these advantages, it has been used for coating metallic substrates with $\mathrm{HAp}, \mathrm{CaP}, \mathrm{Si}-$ HAp, Sr-HAp, F-HAp, Mg-HAp, Ag-HAp, Ag-SiCHAp, Ti-Si-N, Ti-N along with others. ${ }^{128,187-195}$ In a recent study, Kumar et al. applied a coating of transitional metal carbides, i.e., $\mathrm{ZrC}$ and $\mathrm{TiC}$, via sputtering to improve the bio-corrosion and antibacterial properties of stainless-steel (SS) 316L. ${ }^{196}$ The coated surfaces provided better anticorrosion properties in an artificial blood plasma (ABP) solution. The coating also proved to have better antibacterial properties. The bacterial adhesion test results clearly provide an overview of the bacterial adhesion and biofilm formation on SS 316L samples, which was absent on TiC- and ZrC-coated SS 316L samples (see Fig. 6).

The amorphous nature of the coating is also a problem in the case of sputtering. However, with the help of heat treatment, a crystalline coating could be achieved. ${ }^{197-199}$ Hamdi et al. illustrated the improvement in adhesion of sputtering-deposited coating via heat treatment. ${ }^{198}$ In this study, a thin $\mathrm{Ag}-\mathrm{TaO}$ film was deposited on SS 316L via magnetron sputtering, which was initially found to be amorphous in nature. With the help of heat treatment, a tremendous improvement in crystallinity and smooth coarsening was obtained (see Fig. 7). A significant enhancement in mechanical properties was also found after heat treatment. Where the scratch distance and critical load was found to be $440 \mu \mathrm{m}$ and $672 \mathrm{mN}$ for the pretreatment coating, it 

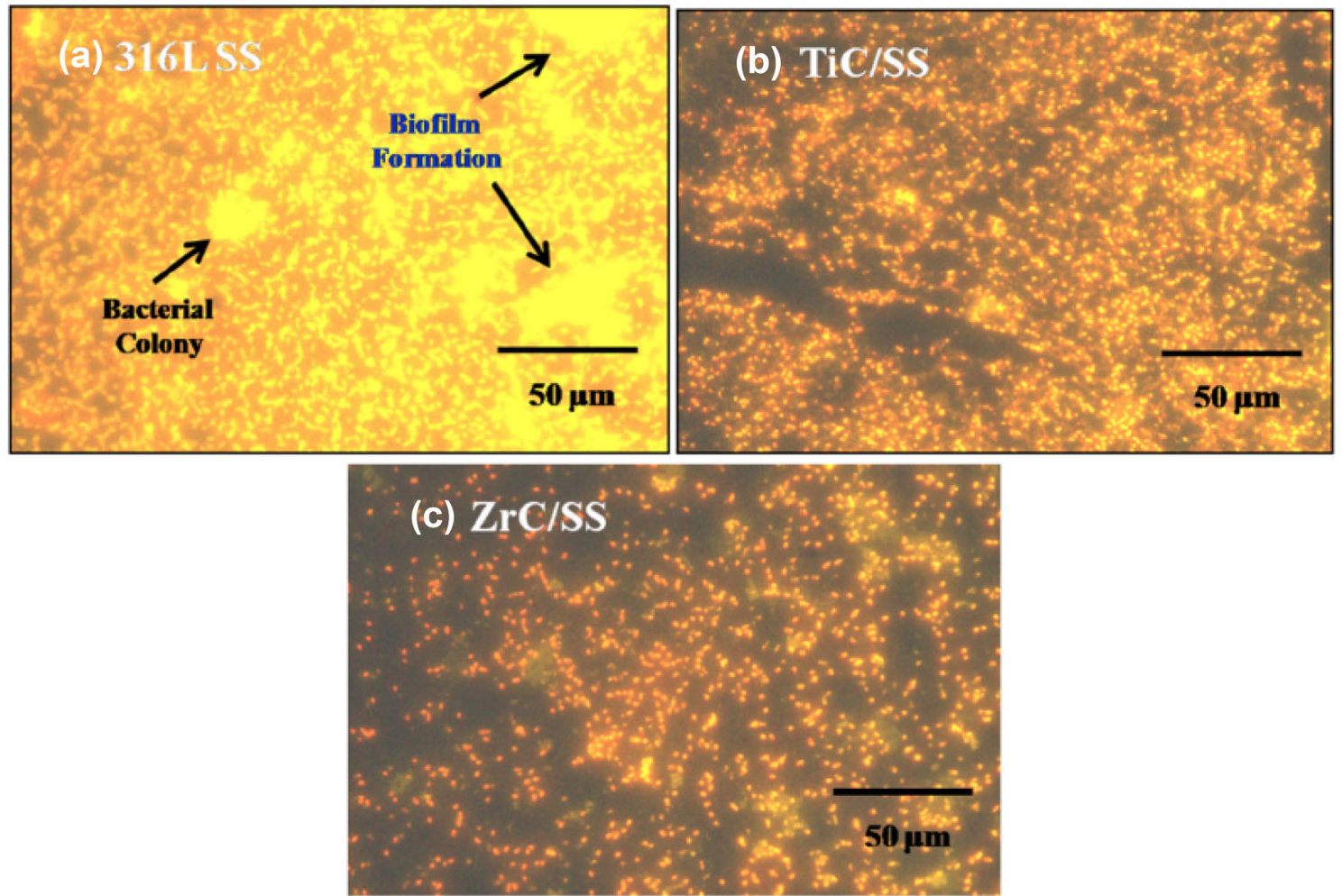

Fig. 6. Epifluorescence microscope images after 4 days of incubation against $P$. aeruginosa of (a) uncoated SS $316 \mathrm{~L}$, (b) TiC-coated and (c) ZrC-coated SS $316 \mathrm{~L}$ substrates. The bacterial adhesion and biofilm formation can be seen for uncoated SS $316 \mathrm{~L}$ substrates, which was prevented by the coating of TiC and ZrC. Reprinted with permission from Ref. 196.
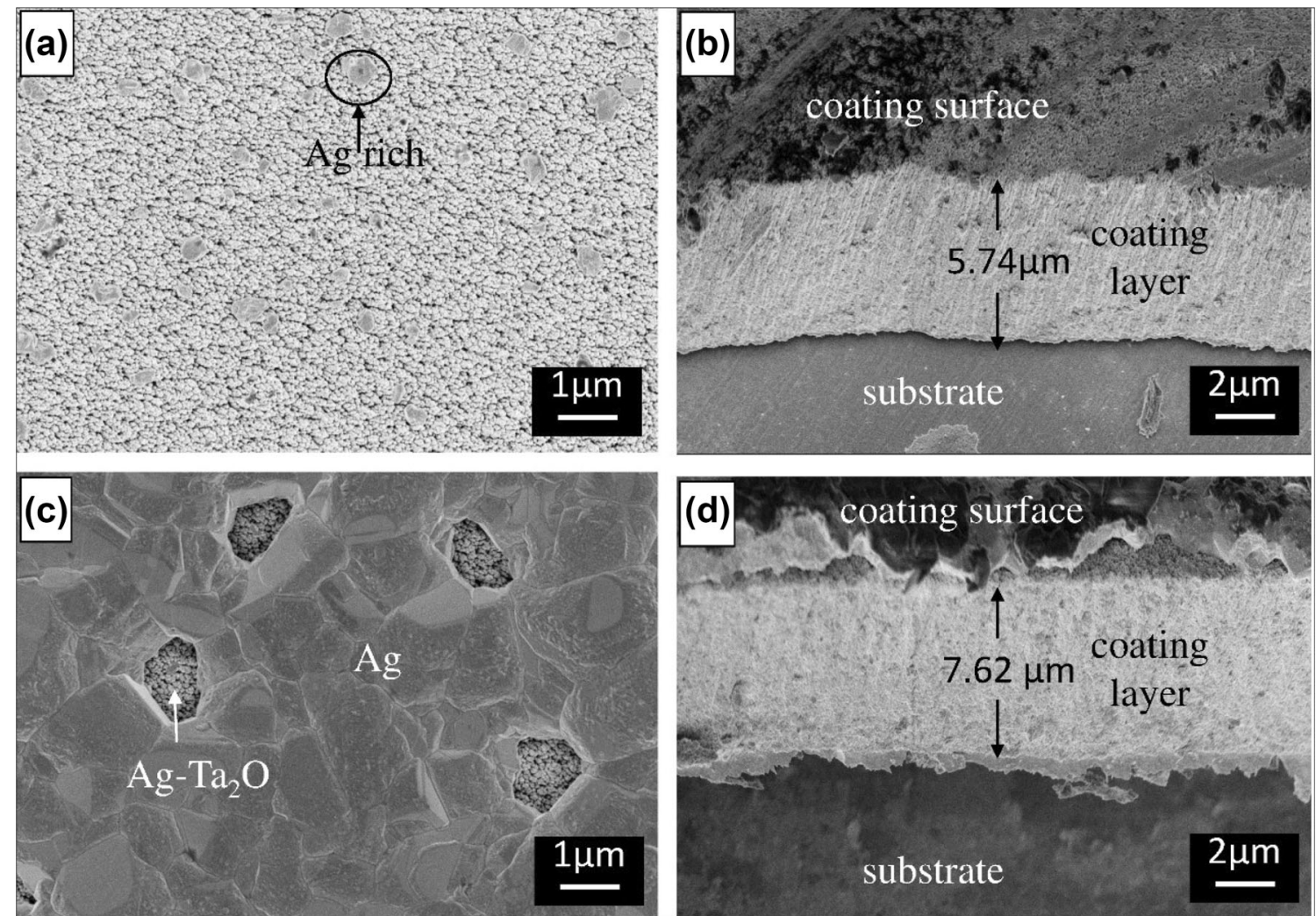

Fig. 7. FESEM surface morphology and cross-section view of Ag-TaO film. a and c Surface morphology of the sputtered film before and after heat treatment. $b$ and d Cross-section of the sputtered film before and after heat treatment. Reprinted with permission from Ref. 198. 
improved to $757 \mu \mathrm{m}$ and $2749 \mathrm{mN}$, respectively, after annealing at $500^{\circ} \mathrm{C}$ for $60 \mathrm{~min}$.

Another popular PVD-based deposition technique for biomedical application is pulsed laser deposition (PLD). In this technique, high-powered laser energy is used to vaporize the to-be-coated material and subsequently deposit on the substrate. ${ }^{200}$ One of the distinct advantages of this technique is its ability to preserve the stoichiometry of the coating after deposition. ${ }^{201,202}$ Given this advantage, a very dense and crystalline coating of HAp is possible via PLD. ${ }^{203-205}$ This is evident in the comparitive study of García-Sanz et al., performed between HAp coating on $\mathrm{Ti}$ produced by plasma spraying and PLD. ${ }^{206}$ Where plasma spraying produced a thick, brittle and inhomogeneous HAp coating, PLD proved to be a better alternative by producing a well-adhered, non-brittle and homogeneous thin coating. However, a low deposition rate, splashing and higher costs have always been major drawbacks to PLD. ${ }^{207}$ Therefore, several variations of PLD such as pulsed electron deposition (PED) and pulsed plasma deposition (PPD) are also being currently investigated for biomedical applications. ${ }^{129,208-211}$

Bianchi et al. investigated the nano-mechanical and in vitro properties of $\mathrm{CaP}$ coatings on $\mathrm{CP} \mathrm{Ti}$ grade 2 processed via PPD technology. ${ }^{208}$ To achieve a crystallized $\mathrm{CaP}$ coating, annealing of the samples was performed for $1 \mathrm{~h}$ at $600^{\circ} \mathrm{C}$. The micro-scratch test results clearly showed the difference in coating adhesion of non-annealed and annealed samples; where spalling/wedging was observed in non-annealed samples, this was absent in the case of the annealed $\mathrm{CaP}$ coating and ductile tensile cracking was observed. Interestingly, in the case of osteoblast cell adhesion and proliferation, no significant difference was observed in annealed and non-annealed $\mathrm{CaP}$ coatings after a 3-day cell culture. This study suggests that the amorphous coating problem in sputtering also occurs in PLD technology.

Another interesting high-temperature coating technique for biomedical applications is hot isostatic pressing (HIP). This process applies high isostatic pressure at high temperatures in an encapsulated system by means of gas to achieve a fully densified ceramic coating. ${ }^{113,130}$ The application of uniform pressure all over the system makes it better than other uniaxial pressing techniques such as hot pressing, as this helps in removing the shape limitation of the substrate for coating. Using HIP, coating of HAp at a relatively low temperature of $135^{\circ} \mathrm{C}$ with a relative density close to that of bone is possible. ${ }^{212}$ In another study, HIP also proved to be a viable technique for coating partially stabilized zirconia (PSZ)/HAp composites. ${ }^{130}$ The low temperature applied in HIP along with the encapsulated system prevents thermal degradation of HAp, providing it a unique advantage compared to other high-temperature coating techniques. ${ }^{130}$

\section{Wet Coating Techniques}

Covalent Bonding Recently, covalent grafting of polymer chains to metal surfaces has been proposed to improve the adhesion, long-term stability and durability between the metal surface and the polymer coating. ${ }^{223-225}$

Thus, many efforts have been made to synthesize grafted polymers to control the polymer thickness and the adhesion strength. ${ }^{226,227}$ Two principal methodologies have been used to link polymer chains on metal surfaces: the "grafting to" or "grafting from" techniques. ${ }^{228-230}$

"Grafting to" requires the synthesis of end-functionalized polymers, i.e., polymer chains terminated with functional groups and their adsorption, through either physical or covalent bonds, to functionalize surfaces. ${ }^{231}$ However, although it makes it possible to characterize the polymer before the grafting reaction, its effectiveness diminishes with the heaviness of the polymer. In fact, the steric repulsions generated by the anchored chains may impede the diffusion of the macromolecules toward the surface, preventing the arrangement of thick and opaque polymer layers. ${ }^{231,232}$

The "grafting to" method allows grafting known structures and often needs an anchor molecule (see Fig. 8). The synthesis of the well-defined polymer was achieved by primarily applying living polymerization techniques, including controlled radical polymerization (CRP). ${ }^{233-235}$ Of these living radical polymerization techniques, three are the most well known: nitroxide-mediated polymerization, atom transfer radical polymerization (ATRP) and reversible addition-fragmentation chain transfer (RAFT) polymerization. These procedures for covalently tying welldefined polymer onto surfaces have been developed, counting the covalent connection of end-functionalized polymers incorporating an appropriate anchor

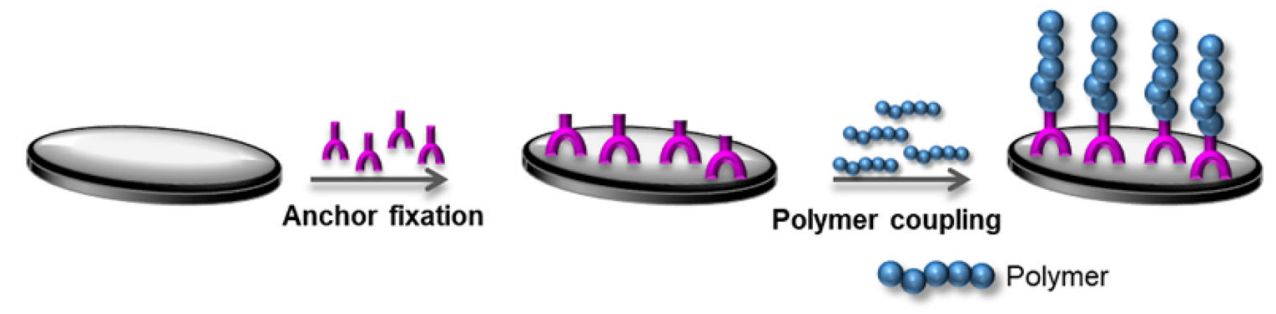

Fig. 8. "Grafting to" process. 


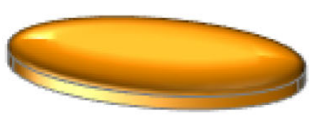

Activation

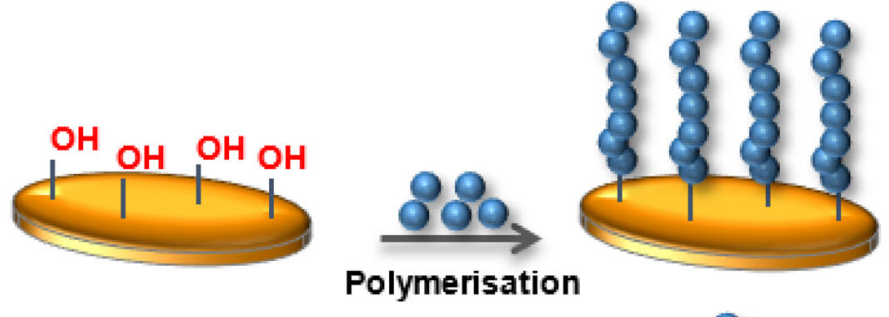

monomer

Fig. 9. "Grafting from" process.

("grafting to") and the in situ polymerization initiated from the surface ("grafting from"). ${ }^{235}$ For example, the most common techniques for the covalent connection of target molecules onto titanium surfaces include the formation of the monolayer with organofunctional silanes, ${ }^{236,237}$ phosphonic acids ${ }^{238-241}$ and phosphonates. ${ }^{242}$ Then, a target molecule was covalently joined to the surface. However, these techniques usually require different steps to create suitable organofunctional anchors. Recently, the catechol unit has become a fundamental biomimetic ligand for surface immobilization. ${ }^{243}$ Inspired by the interesting properties of the adhesive proteins secreted by marine life forms, consolidating the catechol functionality into macromolecules has raised much interest. ${ }^{244-246}$ Messersmith et al. ${ }^{245}$ have detailed the first example of anchoring a catechol initiator onto stainless-steel surfaces for consequent surface initiated ATRP. In this study, the catechol units have been conjugated with different polymerization initiators or "clickable" moieties. ${ }^{134,247}$ For illustration, Woisel et al. ${ }^{245}$ report a flexible and precise approach for titanium surface modification based on catechol surface functionalization that enables target molecules to be attached utilizing the copper-catalyzed azide-alkyne cycloaddition reaction. Chouirfa et al. have developed a simple and flexible methodology based on catechol surface modification that was created to empower bioactive ionic polymers bearing thiol end groups to be attached employing a thiolene click reaction. ${ }^{247,248}$

The "grafting from" method involves the polymer chains' growth from initiator-modified surfaces through surface-initiated polymerizations (see Fig. 9). ${ }^{249}$

This enables less demanding diffusion of monomer molecules toward the propagating radicals fixed on the surface. This infers a higher graft density, allowing denser, thicker and more stable organic layers with better control of the polymer thickness. ${ }^{249,250}$

Non-covalent Bonding Electrophoretic deposition Electrophoretic deposition (EPD) is a simple and versatile colloidal solution-based coating technique for coating at room temperature. It consists of two steps: first, charged particles are moved under the influence of an electric field to the opposite charged electrode. Following this step, the charged particles are deposited via coagulation and precipitation on the electrode surface to form a coating. ${ }^{251}$ EPD is quite a beneficial coating technique for biomedical applications, given to its simple equipment requirements, short processing time, good control in coating thickness, ability to produce interconnected porous coatings and ease of coating even on complex-shaped structures. ${ }^{251-255}$ Given to these advantages, not only biocompatible ceramics ${ }^{256-258}$ and polymers ${ }^{259}$ but also a wide variety of composites have been deposited in metallic implants. ${ }^{260-264}$

In a recent study, PMMA and PMMA-alumina composites have been coated on stainless steel via EPD to improve the bioactivity and osteoconductive properties. $^{265}$ They were able to achieve a homogeneous and porous coating in both cases, where PMMA coating had maximum thickness of $2 \mu \mathrm{m}$ and PMMA-alumina had a coating thickness of $10 \mu \mathrm{m}$. The ALP activity studies confirmed the bioactivity and osteoconductive capacity of both coated surfaces, where maximum bioactivity was found for composite-coated surfaces followed by PMMA-coated surfaces.

Physisorption From a biological perspective, a hydrophilic surface provides a favorable environment for cell growth and osteogenesis by improving protein interaction with the surface. ${ }^{266-268}$ This hydrophilicity can be achieved via physisorption. It is a relatively simple and versatile technique that does not require complex equipment. In this technique, metallic specimens can be directly immersed in the desired polymer solution to achieve polymer physiosorbed metallic substrates. Migonney et al. have used this technique to illustrate how sulfonate and/or carboxylate groups bearing polymers such as PolyNaSS and PAA can be easily physiosorbed on Ti6Al4V surfaces. ${ }^{137}$

Sol-Gel To deposit HAp on metal substrate devoted to implants, plasma spraying, ${ }^{269,270}$ dipping, ${ }^{271}$ electro-co-deposition, ${ }^{272}$ PLD, ${ }^{273}$ sputtering ${ }^{274}$ and 
sol-gel-derived coating ${ }^{275-277}$ have been generally used. Nevertheless, due to the high-temperature process, ${ }^{278}$ plasma spray leads to a lack of crystallinity and the modification of HAp composition.

However, sol-gel is a very versatile and easy method, involving simple fluid flow and evaporation process and generating rather uniform coatings]. ${ }^{279}$ Moreover, sol-gel HAp coatings can be produced at temperatures as low as $900^{\circ} \mathrm{C}$, thus avoiding the decomposition of HAp and $\mathrm{Ti}$ alloy phase transformation.

\section{Mechanical and Wear Properties of Coatings}

Bioceramics are able to directly bond with the surrounding tissue once implanted. ${ }^{280}$ However, typically the principal weakness of these materials originates from the low mechanical strengths making them inappropriate for load-bearing applications.

The mechanical properties and tribological behaviors of $\mathrm{Al}_{2} \mathrm{O}_{3}$ and $\mathrm{HAp}$ have been studied owing to their microstructural features. ${ }^{281-284}$ On the one side the wear mechanisms ${ }^{161}$ and on the other the micro-hardness $(\mathrm{H})$ and elastic modulus $(\mathrm{E})^{285}$ were described using nano-scratch and nano-indentation tests, respectively. The values of $\mathrm{H}$ and $\mathrm{E}$ experimentally determined in Ref. 285 are in good agreement with the data from other studies. ${ }^{286,287}$ Most of the reported $\mathrm{H}$ and $\mathrm{E}$ values for $\mathrm{HAp}$ coatings on $\mathrm{Ti}$ are between $83 \mathrm{GPa}$ and $123 \mathrm{GPa}$ and between $4 \mathrm{GPa}$ and $5 \mathrm{GPa}$, respectively. ${ }^{288}$

The combination of metallic implants and bioceramic thin films brings the advantages of the metal with its mechanical properties and those of the ceramic layer with its bioactive behavior. The mechanical properties are preserved while the integration of the prosthesis with the freshly grown bone is improved. Nonetheless, the metal-ceramics interfaces are frequently the seat of residual stresses. $^{289}$ Their magnitude predominantly depends on the deposition processes and the coating conditions, which can result in high stress and cause a delamination at the interface. ${ }^{161,290-292}$ In Ref. 140, the first mechanical approach to residual stress was reported in a $\mathrm{Ti}$ substrate before and after coating. To obtain accurate residual strains measurements, x-ray diffraction by $\sin ^{2} \psi$ method is the well-adapted technique to overcome problem links to high surface roughness and $<1 \mathrm{~mm}$ layer thickness.

\section{Liquid State Processing}

Due to the economical nature and simplicity of these techniques, they are widely used for metal matrix composite (MMC) preparation. They can be mainly divided into two parts: casting and infiltration.

\section{Casting}

This is one of the most traditional techniques used for manufacturing complex-shaped MMCs in an economical manner. In this process, at first reinforcements are added in liquid metal while continuously stirring to achieve a homogeneous distribution. Liquid material is afterwards poured into a mold with the desired cavity shape and then allowed to solidify. The solidified part is later ejected or broken out of the mold, providing the final part. ${ }^{293}$

Given to its simplicity and efficiency, stir casting is the most common casting technique applied for preparation of metal-matrix composites. In this process, the reinforcements are incorporated into the melt and distributed into the melt via mechanical stirring. The casted composites can be further extruded to reduce the porosity and homogenize the reinforcement distribution. ${ }^{294}$ This technique has been used to incorporate various biomaterials on magnesium and its alloys. ${ }^{70,295-298}$ Khanra et al. have used stir casting and extrusion process to reinforce $\mathrm{Mg}$ and $\mathrm{Mg}-6 \mathrm{Zn}-1 \mathrm{Mn}$ (ZM61) with 5, 10 and 15 wt. $\%$ HAp. ${ }^{295}$ The addition of HAp reinforcements led to an increase in hardness at the expense of ductility. The non-uniform distribution of HAp in the matrix led to lower experimental hardness than theoretically estimated values and irregularities in the tensile strength of composites.

A further improvement in stir casting technique for obtaining a uniform distribution of reinforcement in composite is the high shear solidification technique. In this technique the liquid metal is subjected to intensive shear via high shear rotormixer leading to better mixing of reinforcement in metal matrix. ${ }^{299-302}$ Huang et al. have employed this technique with the equal channel angular extrusion (ECAE) process to successfully develop Mg-HAp nanocomposites. ${ }^{302}$ They initially melted $\mathrm{Mg}$ and added $\mathrm{Zn}$ and $\mathrm{Zr}$ to produce $\mathrm{Mg}-3 \mathrm{Zn}-0.5 \mathrm{Zr}$ alloy in which 1 wt. $\%, 3$ wt. $\%, 5$ wt. $\%$ and 10 wt. $\%$. HAp was added. Afterwards, the ECAE process was performed at a temperature of $300^{\circ} \mathrm{C}$ for several cycles. With the increase in HAp wt.\%, a decrease in grain size was found, where the HAp particles were found to be coupled to the alloy grain-boundary network. In SEM analysis, the individual aggregate of HAp particles was found to be in submicron scale, where some aggregates consist of even only a few HAp particles (see Fig. 10). This shows that the HAp particles were loose and as result were filled and penetrated by matrix alloy during shear mixing. The ECAE process resulted in further grain refinement.

\section{Infiltration}

In this technique, molten matrix metal is impregnated in porous preforms of desired reinforcements, where molten metal fills the pores with or without the application of external force. ${ }^{303}$ It has the 

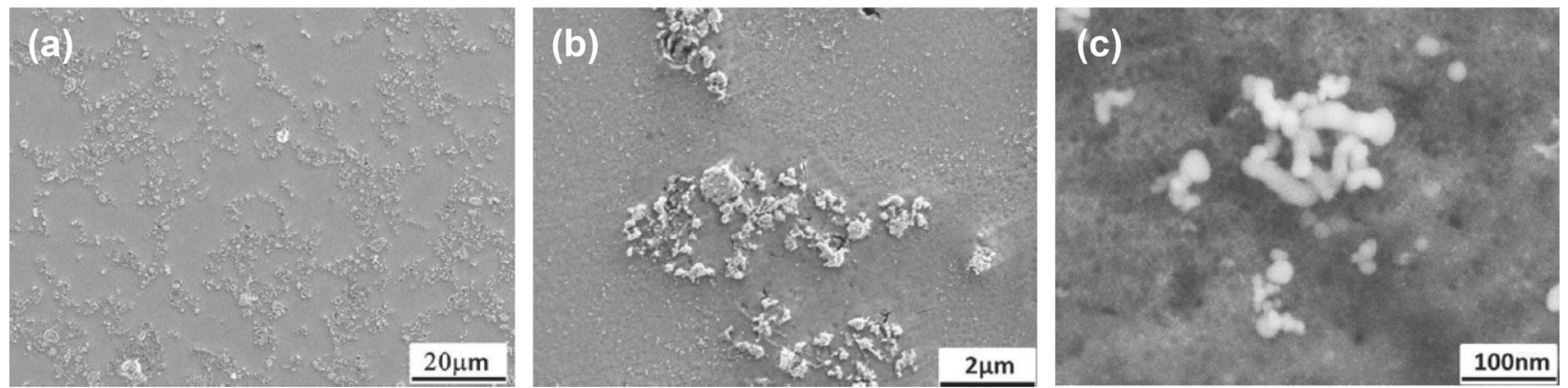

Fig. 10. SEM images of electropolished Mg-3Zn-0.5Zr-5HAp composite at different magnifications. (a) Loose HAp particle aggregates, (b) typical dimensions of these aggregates and (c) fine HAp aggregates containing few HAp particles. Reprinted with permission from Ref. 302.

advantage of preparing MMCs with uniform distribution of reinforcements, eliminating residual porosities and near-net-shaped composite production. ${ }^{304}$

Several interesting studies have been performed to prepare $\mathrm{Mg}$ matrix composites using this technique. ${ }^{305-309}$ Ma et al. have applied this technique to prepare a biodegradable $\beta$-TCP/Mg-Ca composite. ${ }^{306}$ In this study, they initially created the interconnected porous $\beta$-TCP scaffolds by coating PU foams with $\beta$-TCP via slurry coating and sintering at $1100^{\circ} \mathrm{C}$ to burn out PU foam. The prepared scaffolds were infiltrated by $\mathrm{Mg}-1 \mathrm{wt} . \% \mathrm{Ca}$ alloy at a temperature of $700-720^{\circ} \mathrm{C}$ via suction casting. Excellent wettability between $\beta$-TCP and $\mathrm{Mg}$ alloy resulted in full penetration of alloy throughout the porous scaffold (see Fig. 11). Addition of $\mathrm{Mg}$ also led to a tremendous improvement in the compressive strength of the composite, where the ultimate compressive strength of the final composite $(147 \pm 3 \mathrm{MPa})$ was found to be close to that of a bone (180 MPa). The anticorrosion properties of the composite were also found to be better than that of the $\mathrm{Mg}$-Ca alloys.

In a recent study, Myalska et al. have infiltrated a carbon foam with pure $\mathrm{Mg}, \mathrm{Mg}-3 \mathrm{Al}-1 \mathrm{Zn}$ (AZ31) and $\mathrm{Mg}-\mathrm{Zn}-\mathrm{RE}-\mathrm{Zr}$ (RZ5) $\mathrm{Mg}$ alloys in an attempt to develop a new composite material. ${ }^{308}$ They have used the open-celled rectangular carbon foam $\left(C_{\text {of }}\right)$ and pressure infiltration technique. In their study, composite prepared using $\mathrm{Mg}$ and AZ31 alloy showed a good infiltration tendency; this was not found to be the case for RZ5 alloy-based composite. The rare earth elements present in RZ5 alloy had a destructive influence on $C_{\text {of }}$, as along with microand macro-pores, carbon foam damage was also found in this case. Best infiltration was found for $C_{\text {of }} \mathrm{Mg}$ composite with a porosity of only $1.4 \%$, which was slightly worse in the case of AZ31 alloy with a porosity of $2.4 \%$. The reinforcement of carbon foam led to an improvement in compressive strength and stiffness for $\mathrm{Mg}$ and the AZ31 alloy.

\section{Solid-State Processing}

Solid-state processing mostly uses diffusion bonding or sintering for the preparation of metal matrix composites. Processes that use one of those principles for their purpose follow.

\section{Powder Metallurgy}

Powder metallurgy (PM) is the most common route for the development of MMCs. It has the advantage of producing composites with uniform distribution of reinforcements in matrix, requires less temperature and is cost-effective. ${ }^{310}$ It mainly consists of three steps: powder blending, die compaction and sintering. Due to its simplicity and effectiveness, several metal matrix composites have been prepared using this technique for biomedical applications. $^{311-317}$

The final porous structure of the product via this technique is especially helpful in the case of Ti-HAp composites, as it can help in minimizing the elastic modulus and provide osseointegration. ${ }^{34}$ To evaluate this, Ning et al. have performed in vivo and in vitro tests on HAp-Ti composites. ${ }^{314}$ They have prepared $30 \mathrm{wt} . \%, 50 \mathrm{wt} . \%$ and $70 \mathrm{wt} . \%$. Ti-HAp composites via powder metallurgy, sintering at $1200^{\circ} \mathrm{C}$, using $10 \mathrm{wt} . \%$ bioactive glass as a sintering aid. They have used SBF to evaluate the apatite formation characteristics of the composites. They have found a good correlation between the $\mathrm{Ti}$ content in composite to the bioactivity, as apatite formation occurred for the case of 50 and 70Ti-HAp samples, which was not the case for 30Ti-HAp samples. It was suggested that the formation of $\alpha \mathrm{Ti}$ and $\mathrm{Ti}_{2} \mathrm{O}$ on 50 and 70Ti-HAp samples was responsible for apatite formation. For the in vivo study, they implanted the composites on the metaphases of rabbit femur. Where after a month of implantation, bone growth was found to be slow on 30Ti-HAp implants compared to their counterparts, after 6 months of implantation all the Ti-HAp composites formed a good bone-bonding interface with host bone via apatite layer. 

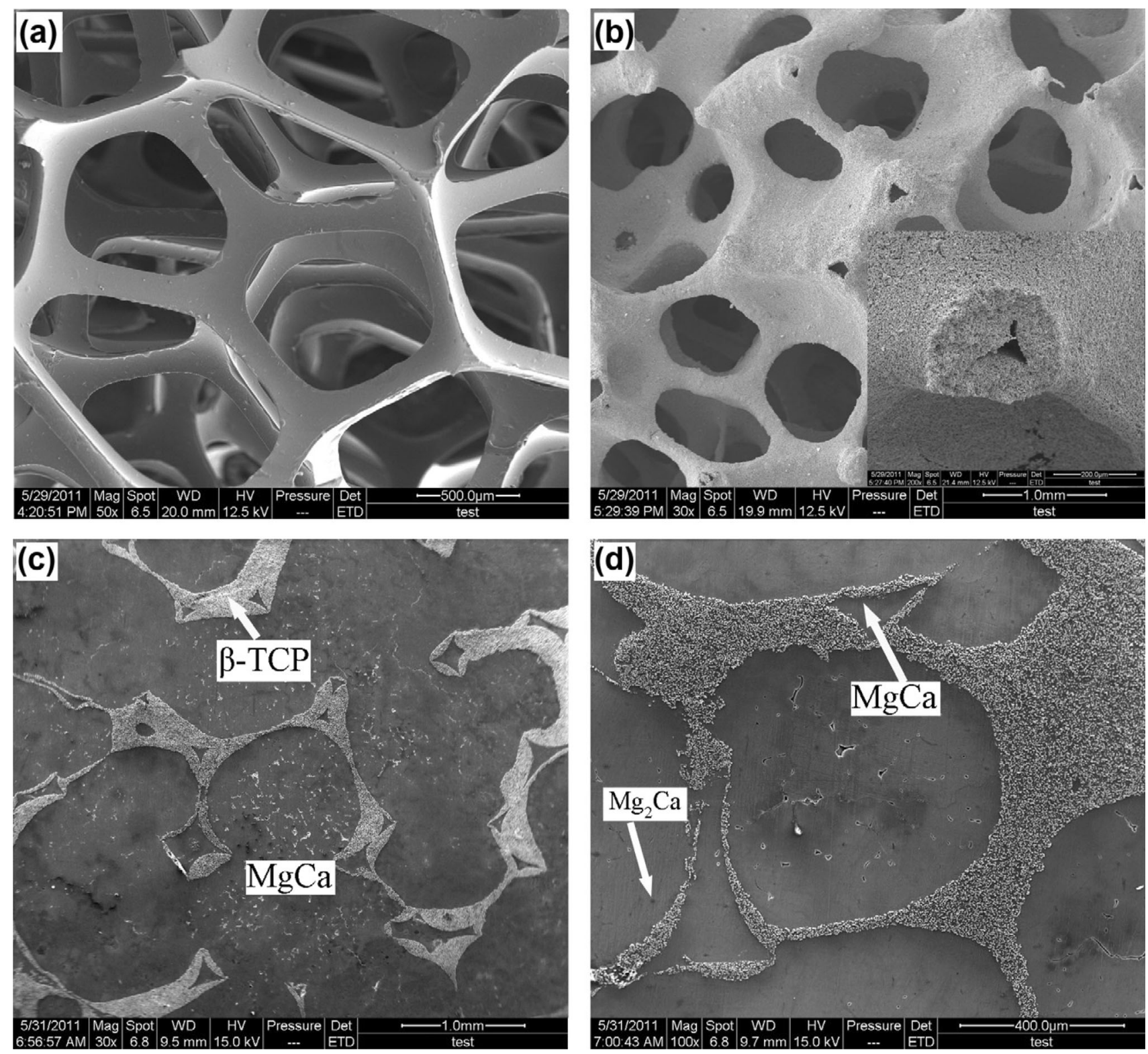

Fig. 11. SEM images of (a) PU foam, (b) porous $\beta$-TCP scaffold, (c) $\beta$-TCP/Mg-Ca composite and (d) the interface between the $\beta$-TCP scaffold and $\mathrm{Mg}$-Ca alloy. The Mg-C- $\beta$-TCP interface had no discernable debonding or microcracks, where the Mg-Ca alloy was also able to penetrate the hollow section of the scaffold. Reprinted with permission from Ref. 306.

Even though HAp is stable up to $1250^{\circ} \mathrm{C}$ in controlled environment, in Ti-HAp systems the presence of Ti leads to accelerated dihydroxylation and decomposition of HAp at temperatures $>800^{\circ} \mathrm{C}$ forming tetracalcium phosphate and calcium oxide. ${ }^{38,319}$ Thus, to minimize this effect, Comin et al. have prepared Ti-20HAp composites using $\mathrm{PM}$, sintering at a temperature of $800^{\circ} \mathrm{C}$ in argon environment for $2 \mathrm{~h} .{ }^{312}$ XRD analysis showed that HAp and Ti existed in their simple forms, suggesting no reaction between HAp and Ti took place during the manufacturing process. The composites have shown great bioactivity and cytocompatibility. After 10 days in SBF solution, the whole surface was found to be covered with apatite. In cell culture study, NIH3T3 cells were able to adhere and proliferate to the whole surface, even to the pores by day 4 of cell culture.

Along with $\mathrm{Ti}$, enhancement in Mg-based implants has also been attained via this technique. Khalajabadi has applied this technique to provide the beneficial properties of $\mathrm{HAp}$ and $\mathrm{TiO}_{2}$ to enhance the biodegradability of Mg-based implants. ${ }^{315}$ The prepared $\mathrm{Mg} / \mathrm{x}_{1} \mathrm{HAp} / \mathrm{x}_{2} \mathrm{TiO}_{2}$ $\left(x_{1}=27.5,20,12.5,5\right.$ and $x_{2}=0,5,10,15$ wt. $\%$, respectively) composite via uniaxial pressing of powder mixture at $\sim 840 \mathrm{MPa}$ in RT followed by sintering at $400^{\circ} \mathrm{C}$ for $1-2 \mathrm{~h}$ in argon environment. 

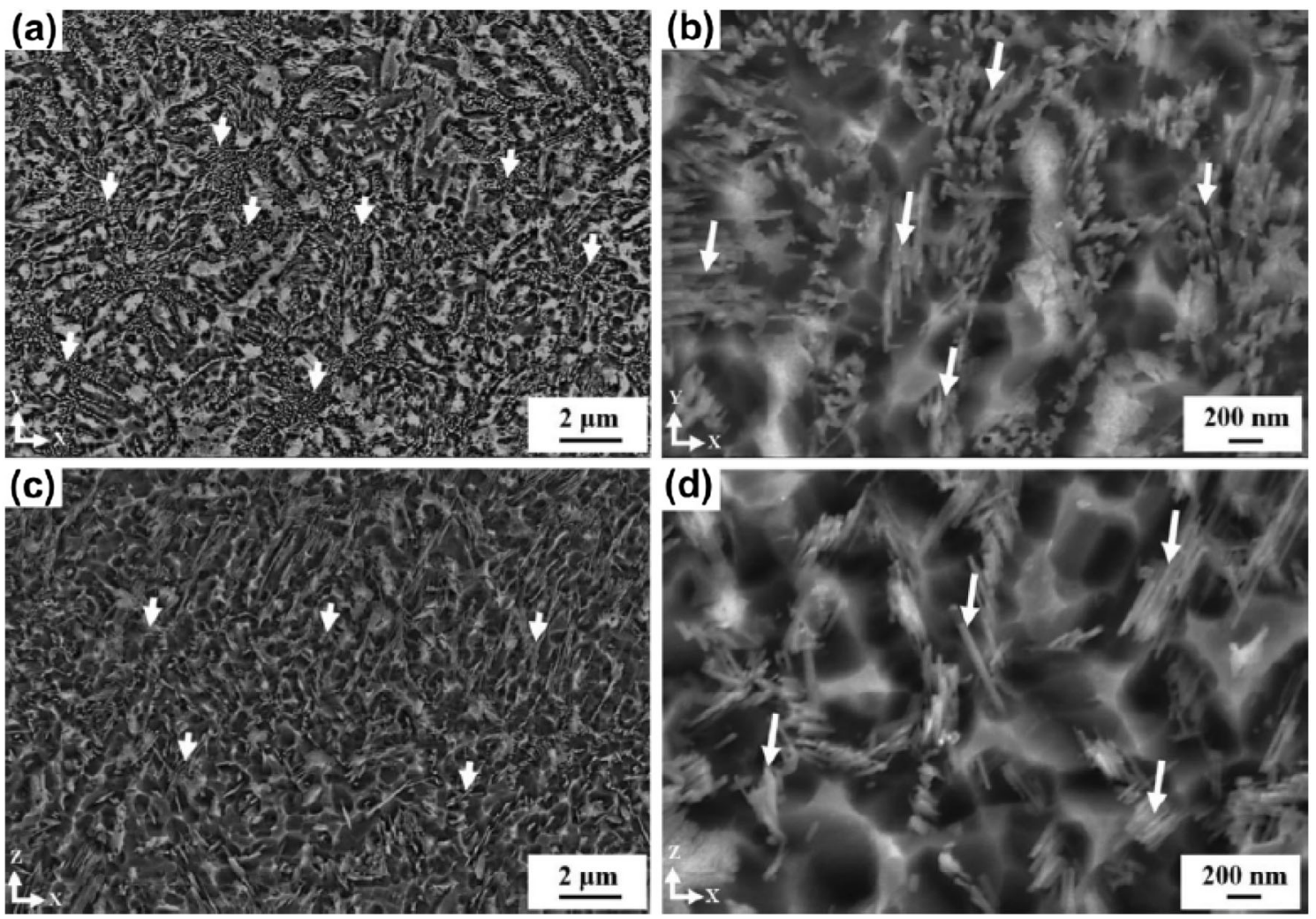

Fig. 12. SEM images of the SLM-produced Ti-TiB composite microstructure at different magnifications: (a, b) cross-sectional views; (c, d) longitudinal views. White arrows indicate TiB particles where the needle-shaped TiB particles within the Ti matrix can be seen. Reprinted with permission from Ref. 326.
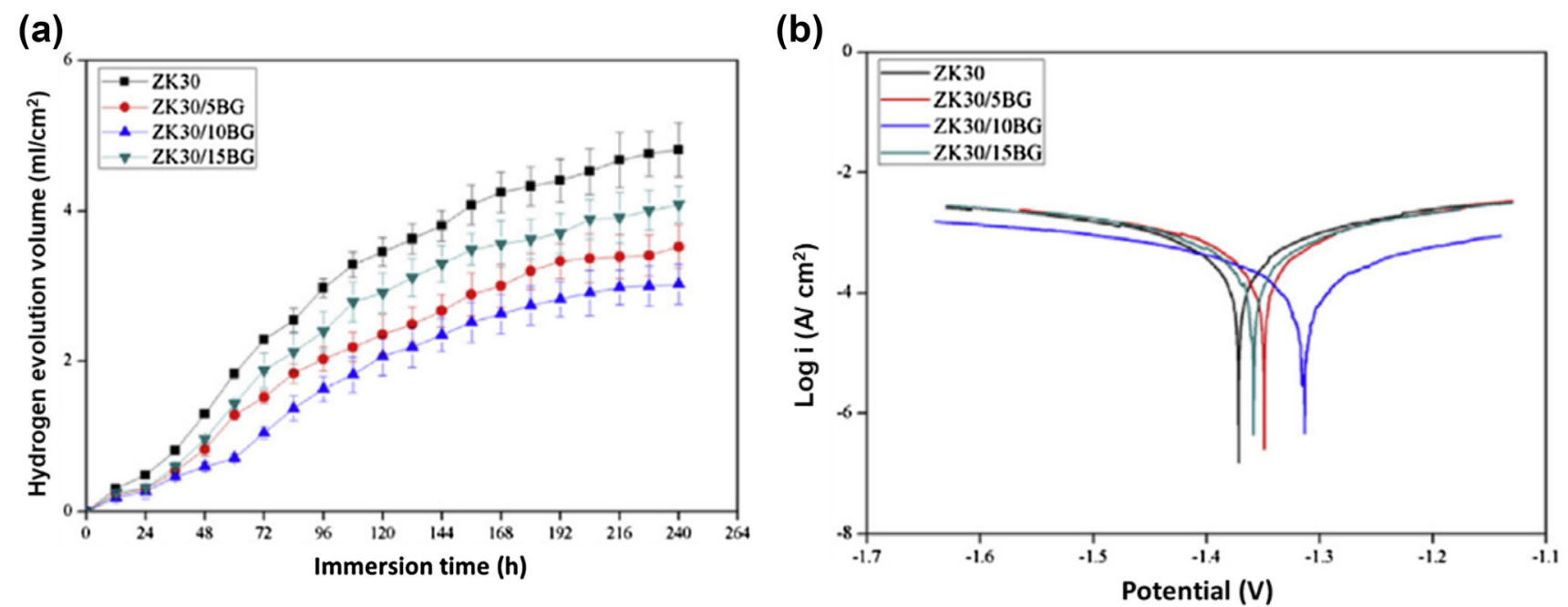

Fig. 13. Hydrogen evolution (a) and Tafel curves (b) of ZK30/xBG composites. Increasing the BG content, the hydrogen evolution and corrosion potential decrease if the BG content does not become too high, i.e., ZK30/15BG. Reprinted with permission from Ref. 321.

The ultimate compressive strength (UCS) and compressive failure strain (CFS) were investigated for all the composites. The highest UCS of $\sim 237 \mathrm{MPa}$ was found for $\mathrm{Mg} / 27.5 \mathrm{HAp}$ samples, where the addition of 5 wt. $\% \mathrm{TiO}_{2}$ and decreasing the HAp to $20 . \%$ led to a decrease of UCS to $\sim 188 \mathrm{MPa}$ but the
CFS had improved from $1.7 \%$ to $1.9 \%$. Interestingly, decreasing the HAp to 5 wt.\% and increasing the $\mathrm{TiO}_{2}$ to 15 wt.\% led to dramatic improvement in UCS from $1.9 \%$ to $8.1 \%$. With higher content of HAp, the agglomeration of HAp particles in the composite causes difficulty in deformation by 
hindering dislocation and hence increase in UCS. The homogeneous distribution of $\mathrm{TiO}_{2}$ led to a decrease in stress concentration and voids near big particles, which helped in improvement of CFS. The addition of $\mathrm{TiO}_{2}$ particles also helped in improving the corrosion behavior by decreasing the number of pores and voids around HAp agglomerates.

In the latest addition, additive manufacturing (AM) technologies utilizing powders as the feed material are taking powder metallurgy to the next level by applying its principle to produce customshaped metal-matrix composites. Selective laser melting (SLM) is the most commonly used AM technology used for producing metal-matrix composite for biomedical applications. ${ }^{67,320-322}$ In this technique, the initial 3D model is provided to machine using CAD software. Afterwards, the powder is laid on the molding platform, which is selectively melted using high-energy laser beams in an inert environment and subsequently solidified, where a new layer is added in a step-by-step fashion creating the final structure. ${ }^{323}$ For production of metal-matrix composites, reinforcements can be incorporated ex situ, where the reinforcement is mixed in metallic powder and subsequently the powder mixture is used for additive manufacturing. ${ }^{324}$ The other way to produce a metal-matrix composite is in situ where the reinforcement is produced in the matrix by chemical reaction between metal matrix and elements or compounds. ${ }^{325}$

To provide better wear and hardness properties to Ti-based composites, TiB has been added as a reinforcement in the production of Ti-TiB composites via in situ SLM. ${ }^{326}$ TiB particles were introduced to the $\mathrm{Ti}$ matrix by an in situ reaction between $\mathrm{Ti}$ and $\mathrm{TiB}_{2}$ during the SLM process, which provided good interfacial bonding between matrix and reinforcements. The TEM analysis identified a significant grain refinement of the $\alpha$-Ti grains due to the presence of $B$ and the rapid solidification. A needle-shaped structure of $\mathrm{TiB}$ was seen in SEM images due to the directional growth of the TiB by the influence of B-B bonds, which are stronger in one direction (see Fig. 12). The addition of TiB led to an improvement in tensile, hardness and compressive strength of the composite.

In a recent study, a biodegradable $\mathrm{Mg}$ alloy/BG composite has been prepared by SLM process. ${ }^{321}$ In this study, ZK30 (Mg-3Zn-0.6Zr) and BG powders were mixed via ball milling and fabricated via SLM to prepare ZK30/xBG $(x=0,5,10,15$ wt.\%) composites. With the addition of higher content of BG, the number and size of pores increased in the composite. In microhardness tests, the hardness of composite increased with the addition of BG but the increase was found to be inhomogeneous. In the degradation rate test, the addition of $\mathrm{BG}$ led to an improvement in hydrogen evolution and corrosion potential of the composites (see Fig. 13). However,
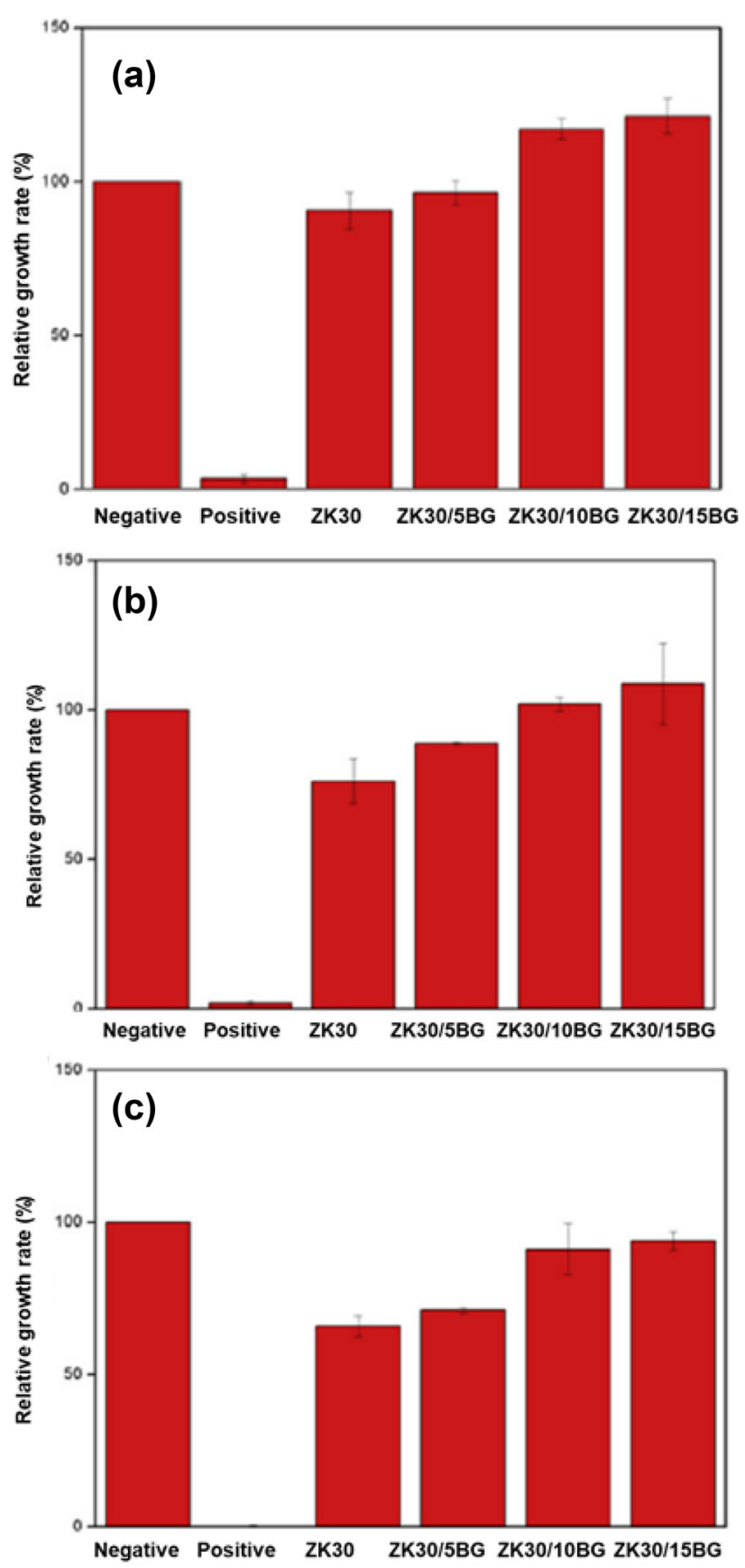

Fig. 14. Relative growth rate of $L 929$ cells on ZK30/xBG composites after (a) $24 \mathrm{~h}$, (b) $48 \mathrm{~h}$ and (c) $72 \mathrm{~h}$. A higher rate in ZK30/10BG and ZK30/15BG can be seen compared to other samples on all days. Adapted with permission from Ref. 321.

the excessive content of BG led to more defects, which accelerated the degradation rate. In cytotoxicity analysis, the increase in BG content enhanced the cytocompatibility as the relative growth rate of L929 cells was higher in ZK30/10BG and ZK30/ 15BG compared to ZK30 and ZK30/5BG composites (see Fig. 14). It was assumed that the reduction in release of $\mathrm{Mg}^{2+}$ and increase in bioactivity by higher content of BG could be responsible for this behavior. 
Table IV. Tensile properties of Ti, PMMA and Ti/PMMA/Ti sandwiches and their theoretically estimated values via RoM.

\begin{tabular}{|c|c|c|c|c|c|c|c|c|c|}
\hline \multirow[b]{2}{*}{ Sample } & \multirow[b]{2}{*}{ Thickness (mm) } & \multirow[b]{2}{*}{$f_{\text {PMMA }}(-)$} & \multicolumn{2}{|c|}{$\mathbf{E}(\mathbf{G P a})$} & \multicolumn{2}{|c|}{ UTS (MPa) } & \multicolumn{2}{|c|}{ YS (MPa) } & \multirow[b]{2}{*}{ ER $(\%)$} \\
\hline & & & Exp. & RoM & Exp. & RoM & Exp. & RoM & \\
\hline $\mathrm{Ti}$ & 0.2 & 0 & $108 \pm 7$ & & $441 \pm 14$ & - & $289 \pm 15$ & - & $27 \pm 1$ \\
\hline PMMA & 0.5 & 1.0 & $2.0 \pm 0.1$ & & $51 \pm 1$ & - & - & - & $6 \pm 1$ \\
\hline Ti/PMMA/Ti & $0.9(0.2 / 0.5 / 0.2)$ & 0.55 & $51 \pm 3$ & 55 & $245 \pm 10$ & 246 & $179 \pm 14$ & 170 & $27 \pm 3$ \\
\hline Ti/PMMA/Ti*1 & $1.4(0.2 / 1.0 / 0.2)$ & 0.71 & - & 32 & - & 162 & - & 119 & $27 * *$ \\
\hline $\mathrm{Ti} / \mathrm{PMMA} / \mathrm{Ti}^{* 2}$ & $2.1(0.4 / 1.5 / 0.2)$ & 0.71 & - & 32 & - & 162 & - & 119 & $27 * *$ \\
\hline
\end{tabular}

Here, $f_{\mathrm{PMMA}}$ : volume fraction of PMMA, ER: elongation to rupture. The values obtained via ROM Ti/PMMA/Ti (0.2/0.5/0.2) are almost equal to the experimentally obtained ones. Reprinted with permission from Ref. 332. *Calculated sandwich combination; **expected, based on the strain at failure of the Ti sheet.

\section{Pressure-Assisted Sandwich Formation}

The interdiffusion between polymers is applied for the preparation of metal/polymer composite in this technique. Metal/polymer composites are generally prepared via accumulative roll bonding in the automotive and aerospace industry where resins are used as adhesion agent ${ }^{327-330}$. However, resins are found to be cytotoxic in nature, which limits this process for biomedical applications. ${ }^{331}$ To overcome this technique, an innovative approach is developed by Reggente et al. where grafted polymers on metal sheets were used as an adhesive agent to prepare $\mathrm{Ti} /$ PMMA/Ti sandwich materials with tunable mechanical properties. ${ }^{332}$ In this study, PMMA chains were initially grafted on $\mathrm{Ti}$ sheets using the "grafting from" technique. ${ }^{333}$ Afterwards, PMMAgrafted Ti sheets and PMMA sheets were pressed together via hot-pressing to prepare Ti/PMMA/Ti sandwiches. The bonding strength was investigated via pull-off and shear tests. The best bonding conditions, i.e., pull-off strength of $\sim 20 \mathrm{MPa}$ and ultimate shear strength of $\sim 10 \mathrm{MPa}$, were obtained at hot-pressing at a temperature of $180^{\circ} \mathrm{C}$ and a pressure of $0.2 \mathrm{MPa}$ for $90 \mathrm{~min}$. The mechanical properties of these sandwiches are easily tunable by varying the PMMA/Ti sheet thickness or quality of the metal. The experimentally obtained tensile properties seemed to correlate with the theoretical values obtained using the rules of mixture (RoM) (Table IV). The Young's modulus of these sandwiches $(\sim 51 \mathrm{GPa})$ was quite close to that of cortical bone; thus, they could minimize the stress shielding problem commonly seen for $\mathrm{Ti}$ implants. The mechanical properties of these sandwiches can be easily reached closer to bone by increasing the ratio of the polymer if keeping the metal sheets' thickness constant. The result obtained from 3-point bending, deep drawing and Erichsen tests of these sandwiches suggested an excellent possibility to shape these sandwiches to fulfill patients' needs.

Thus, this technique can be a new alternative to obtained custom-shaped composites where mechanical properties can also be tuned based on its application area.

\section{CONCLUSION AND OUTLOOK}

The purpose of the current review is to provide a short summary of the possibilities to obtain metalbased composites that can be of use for hard-tissue applications. The most used and emerging techniques have been mentioned in this review. Based on necessity, funds and application area, both biodegradable and bioactive composites can be manufactured. When the need is just to obtain a strong bonding between the surface of implants and the surrounding tissues, coatings seemed to be the way to go. Although thermal spraying is the most used technique in the past, PVD is emerging quickly, given its ease of control and high-quality coatings. Coatings can also be provided via wet techniques in an energy-friendly way.

If the necessity is to develop metal-matrix composites, both liquid-state and solid-state processing could be applied. However, solid-state processing techniques such as PM seemed to provide better end results by providing fine-grain-sized porous microstructures enhancing the cell interaction with the implants. AM is currently the most researched technique for biomedical applications as it minimizes or in some case stops the need for shaping after the manufacturing process by providing custom-shaped parts. Pressure-assisted sandwich formation could also be a promising processing technique in the future as it provides ease of production.

\section{ACKNOWLEDGEMENTS}

We gratefully acknowledge the bilateral financial support provided by the German Research Foundation: Deutsche Forschungsgemeinschaft (DFG), Grant No. PA 837/47-1, and French Research Foundation: Agence nationale de la recherche (ANR), Grant No. ANR-18-CE92-0056. 


\section{FUNDING}

Open Access funding enabled and organized by Projekt DEAL.

\section{CONFLICT OF INTEREST}

The authors declare that they have no conflict of interest.

\section{OPEN ACCESS}

This article is licensed under a Creative Commons Attribution 4.0 International License, which permits use, sharing, adaptation, distribution and reproduction in any medium or format, as long as you give appropriate credit to the original author(s) and the source, provide a link to the Creative Commons licence, and indicate if changes were made. The images or other third party material in this article are included in the article's Creative Commons licence, unless indicated otherwise in a credit line to the material. If material is not included in the article's Creative Commons licence and your intended use is not permitted by statutory regulation or exceeds the permitted use, you will need to obtain permission directly from the copyright holder. To view a copy of this licence, visit $h$ ttp://creativecommons.org/licenses/by/4.0/.

\section{REFERENCES}

1. R. S. Park, J. B. Lakes, Biomaterials: An Introduction, 3rd ed. (Florida, 2007).

2. V. Migonney, Biomaterials 1, 66 (2014).

3. I. M. Gindri, G. V. Salmoria, and J. C. M. Souza, Nanostructured Polymer Matrix Composites for Oral and CranioMaxillofacial Rehabilitation (Elsevier Inc., 2018).

4. J.M. Adkinson, and K.C. Chung, Plast. Reconstr. Surg. 134, 1260 (2014)

5. E. Vorndran, C. Moseke, and U. Gbureck, MRS Bull. 40, 127 (2015).

6. P. Schumann, D. Lindhorst, M.E.H. Wagner, A. Schramm, N.C. Gellrich, and M. Rücker, Pathobiology 80, 211 (2013).

7. B.L. Eppley, A.M. Sadove, and R.Z. German, Plast. Reconstr. Surg. 86, 1085 (1990).

8. J. Oh, Maxillofac. Plast. Reconstr. Surg. 40, 66 (2018).

9. N. J. Hallab and J. J. Jacobs, Orthopedic Applications, Third Edit (Elsevier, 2013).

10. C.M. Crowley, J.T. Pembroke, and C. Birkinshaw, Biomater. Dev. Appl. 6, 66 (2011).

11. N.S. Manam, W.S.W. Harun, D.N.A. Shri, S.A.C. Ghani, T. Kurniawan, M.H. Ismail, and M.H.I. Ibrahim, J. Alloys Compd. 701, 698 (2017).

12. W. Ramakrishna, S. , Mayer, J., 61, 861 (2003).

13. D.J. Bozentka, J. Hand Surg. Am. 18, 1130 (1993).

14. D.F. Williams, Biomaterials 6, 66 (2014).

15. Y.M. Khan, and L.S. Nair, J. Mater. Sci. 6, 66 (2017).

16. S. Thomas, P. Balakrishnan, and M.S. Sreekala, Fundam. Biomater. Ceram. 6, 66 (2018).

17. V. Hasirci, and N. Hasirci, Fundam. Biomater. 6, 66 (2018).

18. P. Parida, A. Behera, and S.C. Mishra, Annu. Inf 1, 125 (2012).

19. L.L. Hench, J. Am. Ceram. Soc. 74, 1487 (1991).

20. L.L. Hench, J. Am. Ceram. Soc. 81, 1705 (2005).

21. W. Cao, and L.L. Hench, Ceram. Int. 22, 493 (1996).

22. S. M. R. B, S. K. K. P, and K. Prabhakar, 43 (2017).

23. J.A. Hubbell, Curr. Opin. Biotechnol. 6, 66 (1999).

24. S. Soni, H. Gupta, N. Kumar, D.K. Nishad, G. Mittal, and A. Bhatnagar, Recent Patr. Biomed. Eng. 3, 30 (2010).
25. N.R. Patel, and P.P. Gohil, Int. J. Emerg. Technol. Adv. Eng. 2, 91 (2012).

26. G.M. Raghavendra, K. Varaprasad, and T. Jayaramudu, Nanotechnol. Appl. Tissue Eng. 21, 66 (2015).

27. W. Murphy and J. Black, Handbook of Biomaterial Properties (Springer, 2016).

28. V.P. Orlovskii, V.S. Komlev, and S.M. Barinov, Inorg. Mater. 38, 1159 (2002).

29. H.-J. Kim, S.-H. Kim, and S.-H. Chang, Compos. Part B Eng. 42, 666 (2011).

30. S. Jana, S.J. Florczyk, M. Leung, and M. Zhang, J. Mater. Chem. 22, 6291 (2012).

31. C.E. Misch, Z. Qu, and M.W. Bidez, J. Oral Maxillofac. Surg. 57, 700 (1999).

32. R.G. Craig, F.A. Peyton, and D.W. Johnson, J. Dent. Res. 40, 936 (1961).

33. Y.R. Zhang, W. Du, X.D. Zhou, and H.Y. Yu, Int. J. Oral Sci. 6, 61 (2014).

34. R.G. Craig, and F.A. Peyton, J. Dent. Res. 37, 710 (1958).

35. H.C. Kim, D. Kim, J.Y. Lee, L. Zhai, and J. Kim, Int. J. Precis. Eng. Manuf. Green Technol. 6, 567 (2019).

36. D.P. Bhattarai, L.E. Aguilar, C.H. Park, and C.S. Kim, Membranes 8, 66 (2018).

37. V. Charu, and D.L. Kaplan, Prog. Polym. Sci. 100, 130 (2012).

38. D. Kasai, R. Chougale, S. Masti, R. Chalannavar, R.B. Malabadi, and R. Gani, J. Appl. Polym. Sci. 135, 66 (2018).

39. M.L. Hassan, N.F. Kassem, and M. El-Sakhawy, Egypt. J. Chem. 58, 299 (2015).

40. M. Greger, V. Masek, and V. Snasel, Methods 2011, 1 (2011).

41. M. Geetha, A.K. Singh, R. Asokamani, and A.K. Gogia, Prog. Mater. Sci. 54, 397 (2009).

42. B. Vrancken, L. Thijs, J.P. Kruth, and J. Van Humbeeck, J. Alloys Compd. 541, 177 (2012).

43. S. J. Dai, Y. Wang, F. Chen, X. Q. Yu, and Y. F. Zhang, Trans. Nonferrous Met. Soc. China (English Ed. 23, 3027 (2013).

44. L. Petrini, and F. Migliavacca, J. Metall. 2011, 1 (2011).

45. P. Ildiko, M. Ladislau, and R. Mario, in Biomater. Regenrative Med., edited by SPi Global (2018), pp. 42-63.

46. H. Hermawan, D. Ramdan, and J. R. P. Djuansjah, in Biomed. Eng. From Theory to Appl., edited by R. Fazel (2011), pp. 412-424.

47. P.A. Dcarnley, Proc. Inst. Mech. Eng. Part H J. Eng. Med. 213, 107 (1999).

48. M. Bahrami, M.H. Fathi, and M. Ahmadian, Mater. Sci. Eng. C 48, 572 (2015).

49. J. Chen, L. Tan, X. Yu, I.P. Etim, M. Ibrahim, and K. Yang, J. Mech. Behav. Biomed. Mater. 87, 68 (2018).

50. H. Hermawan, D. Dubé, and D. Mantovani, Adv. Mater. Res. 15-17, 107 (2007).

51. S. Nayak, B. Bhushan, R. Jayaganthan, P. Gopinath, R.D. Agarwal, and D. Lahiri, J. Mech. Behav. Biomed. Mater. 59,57 (2016).

52. Z. Li, N. Huang, J. Zhao, and S.J. Zhou, Mater. Sci. Technol. 29, 140 (2013).

53. Z. Wen, C. Wu, C. Dai, and F. Yang, J. Alloys Compd. 488, 392 (2009).

54. P. Meagher, E.D. O'Cearbhaill, J.H. Byrne, and D.J. Browne, Adv. Mater. 5755, 66 (2016).

55. T. Kokubo, editor, Bioceramics and Their Clinical Applications, 1st ed. (Woodhead Publishing Limited, 2008).

56. R. M. Vallet, Bio-Ceramics with Clinical Applications, 1st ed. (John Wiley \& Sons, Inc, 2014).

57. L. Sun, H.K. Xu, S. Takagi, and L.C. Chow, J. Biomater. Appl. 21, 299 (2007).

58. I.D. Thompson, and L.L. Hench, Proc. Inst. Mech. Eng. Part H J. Eng. Med. 212, 127 (1998).

59. K. Mediaswanti, C. Wen, E.P. Ivanova, C.C. Berndt, F. Malherbe, V. Thi, H. Pham, and J. Wang, J. Biomim. Biomater. Tissue Eng. 18, 1 (2013).

60. L.L. Zhao, J.J. Su, J. Han, B. Zhang, and L. Ou, RSC Adv. 7, 23065 (2017). 
61. F.T. Moutos, and F. Guilak, Biorheology 45, 501 (2008).

62. J.A. Kaplan, H. Lei, R. Liu, R. Padera, Y.L. Colson, and M.W. Grinstaff, Biomacromol 15, 2548 (2014).

63. H. Hu, R. Zhang, J. Wang, W. Bin Ying, and J. Zhu, Eur. Polym. J. 102, 101 (2018).

64. A.S. Khan, F.S.L. Wong, I.J. McKay, R.A. Whiley, and I.U. Rehman, J. Appl. Polym. Sci. 127, 439 (2012).

65. M. Kisiel, M.M. Martino, M. Ventura, J.A. Hubbell, J. Hilborn, and D.A. Ossipov, Biomaterials 34, 704 (2013).

66. S. Najeeb, M.S. Zafar, Z. Khurshid, and F. Siddiqui, J. Prosthodont. Res. 60, 12 (2016)

67. C. Han, Q. Wang, B. Song, W. Li, Q. Wei, S. Wen, J. Liu, and Y. Shi, J. Mech. Behav. Biomed. Mater. 71, 85 (2017).

68. A.V. Okulov, A.S. Volegov, J. Weissmüller, J. Markmann, and I.V. Okulov, Scr. Mater. 146, 290 (2018).

69. B. Ratna Sunil, C. Ganapathy, T.S. Sampath Kumar, and U. Chakkingal, J. Mech. Behav. Biomed. Mater. 40, 178 (2014).

70. A.K. Khanra, H.W.A.C. Jung, and S.H. Yu, KU. G. S. U. N. Hong 33, 43 (2010).

71. X. Gu, W. Zhou, Y. Zheng, L. Dong, Y. Xi, and D. Chai, Mater. Sci. Eng. C 30, 827 (2010).

72. M. Haneef, J. Rahman, M. Yunus, S. Zameer, S. Patil, and T. Yezdani, Int. J. Mod. Eng. Res 3, 970 (2013).

73. S. Nath, S. Bodhak, and B. Basu, J. Biomed. Mater. Res. Part B Appl. Biomater. 88, 1 (2009).

74. L. Xiaoran, X. Jingwei, L. Justin, Y. Xiaoyan, T. Stavros, and X. Younan, Nano Lett. 9, 2763 (2009).

75. J.C. Reichert, M.E. Wullschleger, A. Cipitria, J. Lienau, T.K. Cheng, M.A. Schütz, G.N. Duda, U. Nöth, J. Eulert, and D.W. Hutmacher, Int. Orthop. 35, 1229 (2011).

76. M. Deng, S.G. Kumbar, L.S. Nair, A.L. Weikel, H.R. Allcock, and C.T. Laurencin, Adv. Funct. Mater. 21, 2641 (2011).

77. S.A. Martel-Estrada, I. Olivas-Armendáriz, C.A. MartínezPérez, T. Hernández, E.I. Acosta-Gómez, J.G. ChacónNava, F. Jiménez-Vega, and P.E. García-Casillas, J. Mater. Sci. Mater. Med. 23, 2893 (2012).

78. Z. Liang, W. Michael. D., and X. Hockin H. K., Biomaterials 31,6502 (2010).

79. H.H.K. Xu, and C.G. Simon, Biomaterials 26, 1337 (2005).

80. R. Song, M. Murphy, C. Li, K. Ting, C. Soo, and Z. Zheng, Drug Des. Devel. Ther. 12, 3117 (2018).

81. M. A. Minnath, Metals and Alloys for Biomedical Applications (Elsevier Ltd, 2018).

82. H.J. Rack, and J.I. Qazi, Mater. Sci. Eng. C 26, 1269 (2006).

83. E.S. Thian, N.H. Loh, K.A. Khor, and S.B. Tor, Biomaterials 23, 2927 (2002).

84. A. Arifin, A.B. Sulong, N. Muhamad, J. Syarif, and M.I. Ramli, Mater. Des. 55, 165 (2014).

85. T.P. Chaturvedi, Mater. Technol. 31, 689 (2016).

86. K. Ishikawa, S. Matsuya, Y. Miyamoto, and K. Kawate, Compr. Struct. Integr. 9, 169 (2007).

87. M. Bahraminasab, B.B. Sahari, K.L. Edwards, F. Farahmand, and M. Arumugam, Mater. Des. 44, 155 (2013).

88. Q. Chen, C. Zhu, and G.A. Thouas, Prog. Biomater. 1, 2 (2012).

89. T.T. Tran, Z.A. Hamid, and K.Y. Cheong, J. Phys. Conf. Ser. 1082, 66 (2018).

90. C. Migliaresi, and L. Nicolais, Int. J. Artif. Organs 3, 114 (1980).

91. W.F. Mousa, M. Kobayashi, S. Shinzato, M. Kamimura, M. Neo, S. Yoshihara, and T. Nakamura, Biomaterials 21, 2137 (2000).

92. B.K. Choi, G.H. Yoon, and S. Lee, Compos. Part B Eng. 91, 119 (2016).

93. M. Ahlhelm, P. Günther, U. Scheithauer, E. Schwarzer, A Günther, T. Slawik, T. Moritz, and A. Michaelis, J. Eur. Ceram. Soc. 36, 2883 (2016).

94. R. Abdullah, N.M.S. Adzali, and Z. Che Daud, Mater. Sci. Forum 819, 337 (2015).

95. A. Atrens, S. Johnston, Z. Shi, and M.S. Dargusch, Scr. Mater. 154, 92 (2018).
96. J. Zhang, W. Zhang, C. Yan, K. Du, and F. Wang, Electrochim. Acta 55, 560 (2009).

97. A. Brown, S. Zaky, H. Ray, and C. Sfeir, Acta Biomater. 11, 543 (2015).

98. H. Gollwitzer, P. Thomas, P. Diehl, E. Steinhauser, B. Summer, S. Barnstorf, L. Gerdesmeyer, W. Mittelmeier, and A. Stemberger, J. Orthop. Res. 23, 802 (2005).

99. A. Visan, R. Cristescu, N. Stefan, M. Miroiu, C. Nita, M. Socol, C. Florica, O. Rasoga, I. Zgura, L.E. Sima, M. Chiritoiu, M.C. Chifiriuc, A.M. Holban, I.N. Mihailescu, and G. Socol, Appl. Surf. Sci. 417, 234 (2017).

100. L. Qin, H. Dong, Z. Mu, Y. Zhang, and G. Dong, Carbohydr. Polym. 133, 236 (2015).

101. L.G. Harris, S. Tosatti, M. Wieland, M. Textor, and R.G. Richards, Biomaterials 25, 4135 (2004).

102. B. Szaraniec, K. Pielichowska, E. Pac, and E. Menaszek, Mater. Sci. Eng. C 93, 950 (2018).

103. F. Zhang, Z. Zhang, X. Zhu, E.T. Kang, and K.G. Neoh, Biomaterials 29, 4751 (2008).

104. H. Frey, and H.R. Khan (eds.), Handbook of Thin-Film Technology (Springer, Berlin, 2015).

105. A.J. Sturgeon, Mater. World 1, 1 (1993).

106. A. Gleadall, Mechanical Properties of Biodegradable Polymers for Medical Applications (Woodhead Publishing Limited, 2014).

107. X. Zheng, M. Huang, and C. Ding, Biomaterials 21, 841 (2000).

108. K.A. Khor, C.S. Yip, and P. Cheang, J. Therm. Spray Technol. 6, 109 (1997).

109. K. Hynynen, A. Darkazanli, C. Damianou, E. Unger, and J. Schenck, Clin. Orthop. Relat. Res. 225, 147 (1987).

110. K.A. Gross, C.C. Berndt, and H. Herman, J. Biomed. Mater. Res. 39, 407 (1998).

111. W.S.W. Harun, R.I.M. Asri, J. Alias, F.H. Zulkifli, K. Kadirgama, S.A.C. Ghani, and J.H.M. Shariffuddin, Ceram. Int. 44, 1250 (2018).

112. A. Dehghanghadikolaei, and B. Fotovvati, Materials 12, 66 (2019).

113. E. Mohseni, E. Zalnezhad, and A.R. Bushroa, Int. J. Adhes. Adhes. 48, 238 (2014).

114. J. Cizek, and J. Matejicek, J. Therm. Spray Technol. 27, 1251 (2018)

115. Y. Niu, X. Liu, and C. Ding, Mater. Sci. Eng. C 28, 1132 (2008).

116. S.J. Zhou, Y. Bai, W. Ma, and W.D. Chen, J. Therm. Spray Technol. 28, 1025 (2019).

117. N. Stiegler, D. Bellucci, G. Bolelli, V. Cannillo, R. Gadow, A. Killinger, L. Lusvarghi, and A. Sola, J. Therm. Spray Technol. 21, 275 (2012).

118. M.F. Morks, and A. Kobayashi, Mater. Sci. Eng. B SolidState Mater. Adv. Technol. 139, 209 (2007).

119. M.F. Morks, J. Mech. Behav. Biomed. Mater. 1, 105 (2008).

120. X. Zhou, R. Siman, L. Lu, and P. Mohanty, Surf. Coat. Technol. 207, 343 (2012)

121. Y. Xie, X. Liu, X. Zheng, and C. Ding, Surf. Coat. Technol. 199, 105 (2005).

122. S. Sathish, M. Geetha, S.T. Aruna, N. Balaji, K.S. Rajam, and R. Asokamani, Wear 271, 934 (2011).

123. H. Herman, S. Sampath, and R. Mccune, 17 (2000).

124. J. Anne, N. Oliver, Y. Su, X. Lu, P.H. Kuo, J. Du, and D. Zhu, Bioact. Mater. 4, 261 (2019).

125. B. Ellison, N.A. Cheney, K.R. Berend, A.V. Lombardi, and T.H. Mallory, J. Orthop. Surg. Res. 4, 1 (2009).

126. R.B. Durairaj, G. Mageshwaran, J. Jeyajeevahan, T. Arvind, J. Hemanandh, M. Kok, and J. Mamallan, Dig. J. Nanomater. Biostruct. 14, 343 (2019).

127. R. Gadow, A. Killinger, and N. Stiegler, Surf. Coat. Technol. 205, 1157 (2010).

128. S. Balasubramanian, A. Ramadoss, A. Kobayashi, and J. Muthirulandi, J. Am. Ceram. Soc. 95, 2746 (2012).

129. G. Graziani, M. Berni, A. Gambardella, M. De Carolis, M.C. Maltarello, M. Boi, G. Carnevale, and M. Bianchi, Mater. Sci. Eng. C 99, 853 (2019). 
130. J. Li, H. Liao, and L. Hermansson, Biomaterials 17, 1787 (1996).

131. A.C.W. Noorakma, H. Zuhailawati, V. Aishvarya, and B.K. Dhindaw, J. Mater. Eng. Perform. 22, 2997 (2013).

132. P. Liu, E. Domingue, D.C. Ayers, J. Song, and A.C.S. Appl, Mater. Interfaces 6, 7141 (2014).

133. M. Ignatova, S. Voccia, B. Gilbert, N. Markova, P.S. Mercuri, M. Galleni, V. Sciannamea, S. Lenoir, D. Cossement, R. Gouttebaron, R. Jérôme, and C. Jérôme, Langmuir 20, 10718 (2004).

134. H. Chouirfa, M.D.M. Evans, P. Bean, A. Saleh-Mghir, A.C. Cremieux, D.G. Castner, C. Falentin-Daudre, V. Migonney, and A.C.S. Appl, Mater. Interfaces 10, 1480 (2018).

135. F. Zhang, E.T. Kang, K.G. Neoh, P. Wang, and K.L. Tan, Biomaterials 22, 1541 (2001).

136. Q. Chen, J. Jing, H. Qi, I. Ahmed, H. Yang, X. Liu, T.L. Lu, A.R. Boccaccini, and A.C.S. Appl, Mater. Interfaces 10, 11529 (2018)

137. C.X. Zhang, C. Falentin-Daudre, and V. Migonney, Biomed. Mater. Eng. 27, 657 (2016).

138. I. Karacan, B. Ben-Nissan, H.A. Wang, A. Juritza, M.V. Swain, W.H. Müller, J. Chou, A. Stamboulis, I.J. Macha, and V. Taraschi, Mater. Sci. Eng. C 104, 109757 (2019).

139. J. Luo, X. Jia, R. Gu, P. Zhou, Y. Huang, J. Sun, and M. Yan, Metals 8, 66 (2018).

140. A. Carradò, and N. Viart, Solid State Sci. 12, 1047 (2010).

141. M. Roy, A. Bandyopadhyay, and S. Bose, Surf. Coat. Technol. 205, 2785 (2011).

142. J.M. Schneider, W.D. Sproul, and A. Matthews, Surf. Coat. Technol. 98, 1473 (1998).

143. M. Kamoshida, I.V. Mitchell, and J.W. Mayer, Appl. Phys. Lett. 18, 292 (1971).

144. T. Tsujide, and K. Iida, Jpn. J. Appl. Phys. 11, 1599 (1972).

145. A.-W. Xu, J.C. Yu, H.-X. Zhang, L.-Z. Zhang, D.-B. Kuang, and Y.-P. Fang, Langmuir 18, 9570 (2002).

146. K.K. Akurati, S.S. Bhattacharya, M. Winterer, and H. Hahn, J. Phys. D. Appl. Phys. 39, 2248 (2006).

147. D. Schwingel, R. Taylor, T. Haubold, J. Wigren, and C. Gualco, Surf. Coat. Technol. 108-109, 99 (1998).

148. D.E. Ruddell, B.R. Stoner, and J.Y. Thompson, Thin Solid Films 445, 14 (2003).

149. T. Houzouji, N. Saito, A. Kudo, and T. Sakata, Chem. Phys. Lett. 254, 109 (1996).

150. V. Pârvulescu, V.I. Pârvulescu, and P. Grange, Catal. Today 57, 193 (2000).

151. A. Husmann, J. Gottmann, T. Klotzbücher, and E.W. Kreutz, Surf. Coat. Technol. 100-101, 411 (1998).

152. Y. Perera, G. Schlaghecken, J. Gottmann, E.W. Kreutz, and R. Poprawe, Key Eng. Mater. 206-213, 547 (2001).

153. H. Szymanowski, A. Sobczyk, M. Gazicki-Lipman, W. Jakubowski, and L. Klimek, Surf. Coat. Technol. 200, 1036 (2005).

154. U. Gunputh and H. Le, in Biomed. Compos. (Elsevier, 2017), pp. 111-138.

155. E. Speets, P.M. te Riele, M.A.F. van den Boogaart, L.M. Doeswijk, B.J. Ravoo, A.J.H.M. Rjinders, J.P. Brugger, J. Brugger, D. Reinhoudt, and D.H.A. Blank, Adv. Funct. Mater. 16, 1337 (2006).

156. A. Hatton, J.E. Nevelos, A.A. Nevelos, R.E. Banks, J. Fisher, and E. Ingham, Biomaterials 23, 3429 (2002).

157. Y.X. Leng, P. Yang, J.Y. Chen, H. Sun, J. Wang, G.J. Wang, N. Huang, X.B. Tian, and P.K. Chu, Surf. Coat. Technol. 138, 296 (2001)

158. A. Matthews and K. Holmberg, Coatings Tribology Properties, Techniques and Applications in Surface Engineering (Elsevier, 1994).

159. C.-T. Kao, S.-J. Ding, Y.-C. Chen, and T.-H. Huang, J. Biomed. Mater. Res. 63, 786 (2002).

160. A. Carradò, G. Schmerber, and H. Pelletier, J. Coat. Technol. Res. 7, 821 (2010).

161. H. Pelletier, A. Carradò, J. Faerber, and I.N. Mihailescu, Appl. Phys. A 102, 629 (2011).

162. V.O. Fasiku, V.O. Fasiku, S.J. Owonubi, E. Mukwevho, B. Aderibigbe, E.R. Sadiku, Y. Lemmer, I.D. Ibrahim, J. Mo- chane, O.O. Daramola, K. Selatile, A. Ndamase, O. Agboola, and O. Agboola, Adv. Coat. Mater. 481, 66 (2018).

163. A. Chebbi, and J. Stokes, J. Therm. Spray Technol. 21, 719 (2012).

164. T. Zhang, D.T. Gawne, and Y. Bao, Surf. Coat. Technol. 96, 337 (1997).

165. B.C. Cheng, S. Koduri, C.A. Wing, N. Woolery, D.J. Cook, and R.C. Spiro, Med. Devices Evid. Res. 11, 391 (2018).

166. M.F. Morks, and A. Kobayashi, Appl. Surf. Sci. 253, 7136 (2007).

167. M. Stilling, O. Rahbek, and K. Søballe, Clin. Orthop. Relat. Res. 467, 2872 (2009).

168. L. Sun, C.C. Berndt, K.A. Gross, and A. Kucuk, J. Biomed. Mater. Res. 58, 570 (2001).

169. Y. Liu, H. Li, and B.T. Zhang, Adv. Nanomater. Coat. Therm. Spray 291, 66 (2019).

170. A. Carradó, and A.C.S. Appl, Mater. Interfaces 2, 561 (2010).

171. S. Vahabzadeh, M. Roy, A. Bandyopadhyay, and S. Bose, Acta Biomater. 17, 47 (2015).

172. S.Q. Fan, G.J. Yang, C.J. Li, G.J. Liu, C.X. Li, and L.Z Zhang, Proc. Int. Therm. Spray Conf. 15, 513 (2006).

173. J. Akedo, Mater. Sci. Forum 449-452, 43 (2004).

174. X. Zhou, and P. Mohanty, Electrochim. Acta 65, 134 (2012).

175. D. Li, X. Chen, Y. Gong, B. Zhang, Y. Liu, P. Jin, and H. Li, Adv. Eng. Mater. 19, 1 (2017).

176. W. Li, H. Assadi, F. Gaertner, and S. Yin, Crit. Rev. Solid State Mater. Sci. 44, 109 (2018).

177. Y. Liu, J. Huang, H. Li, Y. Liu, J. Huang, H. Li, R. Technologies, and P. Technologies, J. Therm. Spray Technol. 23, 1149 (2014).

178. Y. Liu, Z. Dang, Y. Wang, J. Huang, and H. Li, Carbon N. Y. 67, 250 (2014).

179. D. Qiu, M. Zhang, and L. Grøndahl, J. Biomed. Mater. Res. Part A 101 A, 862 (2013).

180. N. Sanpo, M.L. Tan, P. Cheang, and K.A. Khor, J. Therm. Spray Technol. 18, 10 (2009).

181. J.R. Tang, Z.P. Zhao, X.Y. Cui, J.Q. Wang, and T.Y. Xiong, Sci. China Technol. Sci. 6, 66 (2020).

182. D.D. Deligianni, N.D. Katsala, P.G. Koutsoukos, and Y.F. Missirlis, Biomaterials 22, 87 (2000).

183. A. Zareidoost, M. Yousefpour, and B. Ghaseme, A. Amanzadeh 23, 1479 (2012).

184. A. Anders, J. Appl. Phys. 121, 66 (2017).

185. M. Qadir, Y. Li, and C. Wen, Acta Biomater. 89, 14 (2019).

186. K. Koski, J. Hölsä, J. Ernoult, and A. Rouzaud, Surf. Coat. Technol. 6, 66 (1996).

187. A. Nemati, M. Saghafi, S. Khamseh, E. Alibakhshi, P. Zarrintaj, and M.R. Saeb, Surf. Coat. Technol. 349, 251 (2018).

188. E.S. Thian, J. Huang, S.M. Best, Z.H. Barber, and W. Bonfield, Mater. Sci. Eng. C 27, 251 (2007).

189. L.E. Sima, G.E. Stan, C.O. Morosanu, A. Melinescu, A Ianculescu, R. Melinte, J. Neamtu, and S.M. Petrescu, J. Biomed. Mater. Res. Part A 95, 1203 (2010).

190. E.O. López, A.L. Rossi, B.S. Archanjo, R.O. Ospina, A. Mello, and A.M. Rossi, Surf. Coat. Technol. 264, 163 (2015).

191. A.A. Ivanova, M.A. Surmeneva, A.I. Tyurin, T.S. Pirozhkova, I.A. Shuvarin, O. Prymak, M. Epple, M.V. Chaikina, and R.A. Surmenev, Appl. Surf. Sci. 360, 929 (2016).

192. Z. Hong, A. Mello, T. Yoshida, L. Luan, P.H. Stern, A. Rossi, D.E. Ellis, and J.B. Ketterson, J. Biomed. Mater. Res. Part A 93, 878 (2010).

193. M. Badea, M. Braic, A. Kiss, M. Moga, E. Pozna, I. Pana, and A. Vladescu, Ceram. Int. 42, 1801 (2016).

194. M.A. Surmeneva, R.A. Surmenev, A.I. Tyurin, T.M. Mukhametkaliyev, A.D. Teresov, N.N. Koval, T.S. Pirozhkova, I.A. Shuvarin, and C. Oehr, Thin Solid Films 571, 218 (2014).

195. A.R. Boyd, L. Rutledge, L.D. Randolph, and B.J. Meenan, Mater. Sci. Eng. C 46, 290 (2015). 
196. D.D. Kumar, G.S. Kaliaraj, A.M.K. Kirubaharan, K. Alagarsamy, V. Vishwakarma, and R. Baskaran, Surf. Coat. Technol. 374, 569 (2019).

197. J. Wu, K. Ueda, and T. Narushima, Mater. Sci. Eng. C 109, 110599 (2020).

198. R. Alias, R. Mahmoodian, M.H.A. Shukor, B.S. Yew, and M. Muhamad, AIP Conf. Proc. 1948, 66 (2018).

199. R.V. Chernozem, M.A. Surmeneva, B. Krause, T. Baumbach, V.P. Ignatov, A.I. Tyurin, K. Loza, M. Epple, and R.A. Surmenev, Appl. Surf. Sci. 426, 229 (2017).

200. F. Sima, C. Ristoscu, L. Duta, O. Gallet, K. Anselme, and I. N. Mihailescu, Laser Thin Films Deposition and Characterization for Biomedical Applications (Elsevier Ltd, 2016).

201. I.W. Boyd, Ceram. Int. 22, 429 (1996).

202. V. Nelea, I.N. Mihailescu, and M. Jelínek, Pulsed Laser Depos. Thin Film Appl. Growth Funct. Mater. 421, 66 (2007).

203. L. Duta, and A.C. Popescu, Coatings 9, 66 (2019).

204. L. Clèries, J.M. Fernández-Pradas, and J.L. Morenza, $J$. Biomed. Mater. Res. 49, 43 (2000).

205. G.C. Gomes, F.F. Borghi, R.O. Ospina, E.O. López, F.O. Borges, and A. Mello, Surf. Coat. Technol. 329, 174 (2017).

206. F.J. García-Sanz, M.B. Mayor, J.L. Arias, J. Pou, B. León, and M. Pérez-Amor, J. Mater. Sci. Mater. Med. 8, 861 (1997).

207. A. Liguori, C. Gualandi, M.L. Focarete, F. Biscarini, and M. Bianchi, Coatings 10, 16 (2019).

208. M. Boi, M. Bianchi, A. Gambardella, F. Liscio, S. Kaciulis, A. Visani, M. Barbalinardo, F. Valle, M. Iafisco, L. Lungaro, S. Milita, M. Cavallini, M. Marcacci, and A. Russo, RSC Adv. 5, 78561 (2015).

209. M. Bianchi, A. Gambardella, M. Berni, S. Panseri, M. Montesi, N. Lopomo, A. Tampieri, M. Marcacci, and A. Russo, J. Mater. Sci. Mater. Med. 27, 1 (2016).

210. D. Bellucci, M. Bianchi, G. Graziani, A. Gambardella, M. Berni, A. Russo, and V. Cannillo, Ceram. Int. 43, 15862 (2017).

211. M. Bianchi, A. Russo, N. Lopomo, M. Boi, M.C. Maltarello, S. Sprio, M. Baracchi, and M. Marcacci, J. Mater. Chem. B 1, 310 (2013).

212. T. Onoki, and T. Hashida, Surf. Coat. Technol. 200, 6801 (2006).

213. K. Yao, S. Chen, K. Guo, C.K.I. Tan, M.S. Mirshekarloo, and F.E.H. Tay, IEEE Trans. Ultrason. Ferroelectr. Freq. Control 64, 1758 (2017).

214. S. Yugeswaran, C.P. Yoganand, A. Kobayashi, K.M. Paraskevopoulos, and B. Subramanian, J. Mech. Behav. Biomed. Mater. 9, 22 (2012).

215. N.B.S. Magagula, N. Sacks, and I. Botef, J. S. Afr. Inst. Min. Metall. 116, 333 (2016).

216. A.M. Vilardell, N. Cinca, A. Concustell, S. Dosta, I.G. Cano, and J.M. Guilemany, J. Mater. Sci. 50, 4441 (2015).

217. J. Karthikeyan, Cold Spray Mater. Depos. Process. Fundam. Appl. 62, 66 (2007).

218. M. S. M, V. G, K. MS, B. K. Sridhara, and T. N. Shridhar, IOP Conf. Ser. Mater. Sci. Eng. 149, 012071 (2016).

219. J.A. Toque, M.K. Herliansyah, M. Hamdi, A. Ide-Ektessabi, and I. Sopyan, J. Mech. Behav. Biomed. Mater. 3, 324 (2010).

220. H. Soonmin, S.A. Vanalakar, A. Galal, and V.N. Singh, Mediterr. J. Chem. 7, 433 (2018).

221. A.V. Muley, S. Aravindan, and I.P. Singh, Manuf. Rev. 2, 66 (2015).

222. M.H. Bocanegra-Bernal, J. Mater. Sci. 9, 6399 (2004).

223. C. Sun, F. Zhou, L. Shi, B. Yu, P. Gao, J. Zhang, and W. Liu, Appl. Surf. Sci. 253, 1729 (2006).

224. K. Shimizu, K. Malmos, S.-A. Spiegelhauer, J. Hinke, A.H Holm, S.U. Pedersen, K. Daasbjerg, and M. Hinge, Int. J. Adhes. Adhes. 51, 1 (2014).

225. O. Alageel, M.-N. Abdallah, Z.Y. Luo, J. Del-Rio-Highsmith, M. Cerruti, and F. Tamimi, Dent. Mater. 31, 105 (2015).
226. K. Shimizu, K. Malmos, A.H. Holm, S.U. Pedersen, K. Daasbjerg, M. Hinge, and A.C.S. Appl, Mater. Interfaces 6, 21308 (2014).

227. B. Zhao, and W.J. Brittain, Prog. Polym. Sci. 25, 677 (2000).

228. A. Balazs, Prog. Surf. Sci. 55, 181 (1997).

229. A. Bhattacharya, Prog. Polym. Sci. 29, 767 (2004).

230. D. Li, Q. Zheng, Y. Wang, and H. Chen, Polym. Chem. 5, 14 (2014).

231. B. Zdyrko, and I. Luzinov, Macromol. Rapid Commun. 32, 859 (2011).

232. D.P. Sweat, M. Kim, X. Yu, and P. Gopalan, Langmuir 29, 3805 (2013).

233. V. Coessens, T. Pintauer, and K. Matyjaszewski, Prog. Polym. Sci. 26, 337 (2001)

234. C.J. Hawker, A.W. Bosman, and E. Harth, Chem. Rev. 101, 3661 (2001).

235. G. Moad, Y.K. Chong, A. Postma, E. Rizzardo, and S.H. Thang, Polymer (Guildf). 46, 8458 (2005).

236. X. Jia, X. Jiang, R. Liu, and J. Yin, Macromol. Chem. Phys. 210, 1876 (2009).

237. M.C. Porté-Durrieu, F. Guillemot, S. Pallu, C. Labrugère, B. Brouillaud, R. Bareille, J. Amédée, N. Barthe, M. Dard, and C. Baquey, Biomaterials 25, 4837 (2004).

238. M. Reggente, S. Kriegel, W. He, P. Masson, G. Pourroy, F. Mura, J. Faerber, D. Passeri, M. Rossi, H. Palkowski, and A. Carradò, Pure Appl. Chem. 6, 66 (2019).

239. C. Viornery, Y. Chevolot, D. Léonard, B.-O. Aronsson, P. Péchy, H.J. Mathieu, P. Descouts, and M. Grätzel, Langmuir 18, 2582 (2002).

240. V. Zoulalian, S. Monge, S. Zürcher, M. Textor, J.J. Robin, and S. Tosatti, J. Phys. Chem. B 110, 25603 (2006).

241. N. Adden, L.J. Gamble, D.G. Castner, A. Hoffmann, G. Gross, and H. Menzel, Langmuir 22, 8197 (2006).

242. M.A. White, A. Maliakal, N.J. Turro, and J. Koberstein, Macromol. Rapid Commun. 29, 1544 (2008).

243. E. Faure, C. Falentin-Daudré, C. Jérôme, J. Lyskawa, D. Fournier, P. Woisel, and C. Detrembleur, Prog. Polym. Sci. 38,236 (2013).

244. J. Liu, W. Yang, H.M. Zareie, J.J. Gooding, and T.P. Davis, Macromolecules 42, 2931 (2009).

245. M.A. Watson, J. Lyskawa, C. Zobrist, D. Fournier, M. Jimenez, M. Traisnel, L. Gengembre, and P. Woisel, Langmuir 26, 15920 (2010).

246. X. Fan, L. Lin, J.L. Dalsin, and P.B. Messersmith, J. Am. Chem. Soc. 127, 15843 (2005)

247. H. Chouirfa, M.D.M. Evans, D.G. Castner, P. Bean, D. Mercier, A. Galtayries, C. Falentin-Daudré, and V. Migonney, Biointerphases 12, 02C418 (2017).

248. H. Chouirfa, V. Migonney, and C. Falentin-Daudré, RSC Adv. 6, 13766 (2016).

249. R. Barbey, L. Lavanant, D. Paripovic, N. Schüwer, C. Sugnaux, S. Tugulu, and H.-A. Klok, Chem. Rev. 109, 5437 (2009).

250. S. Minko, in Polym. Surfaces Interfaces (Springer, Berlin, 2008), pp. 215-234.

251. E. Avcu, F.E. Bastan, H.Z. Abdullah, M.A.U. Rehman, Y.Y. Avcu, and A.R. Boccaccini, Prog. Mater. Sci. 103, 69 (2019).

252. F. Pishbin, A. Simchi, M.P. Ryan, and A.R. Boccaccini, Surf. Coat. Technol. 205, 5260 (2011).

253. S. Seuss, M. Lehmann, and A.R. Boccaccini, Int. J. Mol. Sci. 15, 12231 (2014).

254. S. Xu, R. Zhang, W. Zhao, Y. Zhu, W. Wei, X. Liu, and J. Luo, Biosens. Bioelectron. 92, 570 (2017).

255. F. Gebhardt, S. Seuss, M.C. Turhan, H. Hornberger, S. Virtanen, and A.R. Boccaccini, Mater. Lett. 66, 302 (2012).

256. S. Singh, G. Singh, and N. Bala, Mater. Today Proc. 5, 20160 (2018).

257. A. Stoch, A. Brozek, G. Kmita, J. Stoch, W. Jastrz, and A. Rakowska, J. Mol. Struct. 596, 191 (2001).

258. K.D. Patel, R.K. Singh, J.H. Lee, and H.W. Kim, Mater. Lett. 234, 148 (2019).

259. M. Szklarska, B. Łosiewicz, G. Dercz, J. Maszybrocka, M. Rams-Baron, and S. Stach, RSC Adv. 10, 13386 (2020). 
260. J. Zhang, Z. Wen, M. Zhao, G. Li, and C. Dai, Mater. Sci. Eng. C 58, 992 (2016).

261. A. Molaei, A. Amadeh, M. Yari, and M. Reza Afshar, Mater. Sci. Eng. C 59, 740 (2016).

262. Z. Zhong, J. Qin, and J. Ma, Ceram. Int. 41, 8878 (2015).

263. T. Yoshioka, A. Chávez-Valdez, J.A. Roether, D.W. Schubert, and A.R. Boccaccini, J. Colloid Interface Sci. 392, 167 (2013).

264. L. Cordero-Arias, A.R. Boccaccini, and S. Virtanen, Surf. Coat. Technol. 265, 212 (2015).

265. A. D'Elia, J. Deering, A. Clifford, B.E.J. Lee, K. Grandfield, and I. Zhitomirsky, Colloids Surf. B Biointerfaces 188, 66 (2020).

266. G. Zhao, Z. Schwartz, M. Wieland, F. Rupp, J. Geis-Gerstorfer, D.L. Cochran, and B.D. Boyan, J. Biomed. Mater. Res. Part A 74, 49 (2005).

267. M.M. Bornstein, P. Valderrama, A.A. Jones, T.G. Wilson, R. Seibl, and D.L. Cochran, Clin. Oral Implants Res. 19, 233 (2008).

268. R.E. McMahon, L. Wang, R. Skoracki, and A.B. Mathur, J. Biomed. Mater. Res. Part B Appl. Biomater. 101B, 387 (2013).

269. M. Long, and H.J. Rack, Biomaterials 19, 1621 (1998).

270. J. Weng, X.G. Liu, X.D. Li, and X.D. Zhang, Biomaterials 16, 39 (1995).

271. T. Li, J. Lee, T. Kobayashi, and H. Aoki, J. Mater. Sci. Mater. Med. 7, 355 (1996).

272. H. Dasarathy, C. Riley, H.D. Coble, W.R. Lacefield, and G. Maybee, J. Biomed. Mater. Res. 31, 81 (1996).

273. C.M. Cotell, Appl. Surf. Sci. 69, 140 (1993).

274. J.L. Ong, L.A. Harris, L.C. Lucas, W.R. Lacefield, and D. Rigney, J. Am. Ceram. Soc. 74, 2301 (1991).

275. W. Weng, and J.L. Baptista, J. Mater. Sci. Mater. Med. 9, 159 (1998).

276. J. Xiong, Y. Li, P.D. Hodgson, and C. Wen, Acta Biomater. 6, 1584 (2010).

277. C. Wen, W. Xu, W. Hu, and P. Hodgson, Acta Biomater. 3, 403 (2007).

278. C.Y. Yang, B.C. Wang, E. Chang, and J.D. Wu, J. Mater. Sci. Mater. Med. 6, 249 (1995).

279. X.J. Wang, Y.C. Li, J.G. Lin, P.D. Hodgson, and C.E. Wen, J. Mater. Res. 23, 1682 (2008).

280. L.L. Hench, and C. Wagon, Ceram. Int. 22, 493 (1996).

281. S.S. Pazarlioglu, and S. Salman, J. Aust. Ceram. Soc. 56, 413 (2019).

282. C. McManamon, J.P. de Silva, J. Power, S. Ramirez-Garcia, M.A. Morris, and G.L.W. Cross, Langmuir 30, 11412 (2014).

283. K. Balani, V. Verma, A. Agarwal, and R. Narayan, Biosurfaces: A Materials Science and Engineering Perspective (John Wiley \& Sons, Inc, 2015)

284. S. Durdu, and M. Usta, Ceram. Int. 40, 3627 (2014).

285. W.C. Oliver, and G.M. Pharr, J. Mater. Res. 19, 3 (2004).

286. T.G. Nieh, A.F. Jankowski, and J. Koike, J. Mater. Res. 16, 3238 (2001).

287. A. Dey, A.K. Mukhopadhyay, S. Gangadharan, M.K. Sinha, D. Basu, and N.R. Bandyopadhyay, Ceram. Int. 35, 2295 (2009)

288. C. Zhang, Biomaterials 22, 1357 (2001).

289. I.C. Noyan, and J.B. Cohen, Residual Stress: Measurement by Diffraction and Interpretation (Springer, New York, 1987).

290. L. Longbiao, in Durab. Ceram. Compos. (Elsevier, 2020), pp. 1-73.

291. Y. Yang, Biomaterials 21, 1327 (2000).

292. Y.C. Yang, and E. Chang, Biomaterials 22, 1827 (2001).

293. G. Modlen, Int. J. Prod. Res. 27, 372 (1989).

294. D.B. Taron, Int. J. Sci. Res. Dev. 5, 2321 (2017).

295. A.K. Khanra, H.C. Jung, K.S. Hong, and K.S. Shin, Mater. Sci. Eng. A 527, 6283 (2010).

296. H.K. Khosroshahi, F.F. Saniee, and H.R. Abedi, Mater. Sci. Eng. A 595, 284 (2014).

297. H. Zheng, Z. Li, M. Chen, C. You, and D. Liu, Mater. Sci. Eng. A 715, 205 (2018).
298. L.C. Kumruoglu, Acta Phys. Pol. A 125, 432 (2014).

299. Z. Fan, M. Xia, H. Zhang, G. Liu, J.B. Patel, Z. Bian, I. Bayandorian, Y. Wang, H.T. Li, and G.M. Scamans, Int. J. Cast Met. Res. 22, 103 (2009).

300. M. Razavi, and Y. Huang, Recent Pat. Nanotechnol. 13, 38 (2019).

301. Y. Huang, D. Liu, L. Anguilano, C. You, and M. Chen, Mater. Sci. Eng. C 54, 120 (2015).

302. Y. Huang, J. Li, and L. Zhou, Mater. Sci. Technol. 34, 1868 (2018).

303. K.M. Sree Manu, L. Ajay Raag, T.P.D. Rajan, M. Gupta, and B.C. Pai, Metall. Mater. Trans. B Process Metall. Mater. Process. Sci. 47, 2799 (2016).

304. L.M. Peng, J.W. Cao, K. Noda, and K.S. Han, Mater. Sci. Eng. A 374, 1 (2004).

305. X. Wang, L.H. Dong, J.T. Li, X.L. Li, X.L. Ma, and Y.F. Zheng, Mater. Sci. Eng. C 33, 4266 (2013).

306. X.L. Ma, L.H. Dong, and X. Wang, Mater. Des. 56, 305 (2014).

307. X.N. Gu, X. Wang, N. Li, L. Li, Y.F. Zheng, and X. Miao, J. Biomed. Mater. Res. Part B Appl. Biomater. 99B, 127 (2011).

308. A. Olszówka-Myalska, M. Godzierz, J. Myalski, and P. Wrześniowski, Metals (Basel). 9, (2019).

309. X. Wang, L.H. Dong, X.L. Ma, and Y.F. Zheng, Mater. Sci. Eng. C 33, 618 (2013).

310. M. Meignanamoorthy, and M. Ravichandran, Mech. Mech Eng. 22, 65 (2018).

311. C. Cai, B. Song, C. Qiu, L. Li, P. Xue, Q. Wei, J. Zhou, H. Nan, H. Chen, and Y. Shi, J. Alloys Compd. 710, 364 (2017).

312. R. Comin, M.P. Cid, L. Grinschpun, C. Oldani, and N.A. Salvatierra, J. Appl. Biomater. Funct. Mater. 15, 176 (2017).

313. A. Kumar, T.J. Webster, K. Biswas, and B. Basu, J. Biomed. Mater. Res. Part A 101, 2925 (2013).

314. C. Ning, and Y. Zhou, Acta Biomater. 4, 1944 (2008).

315. S.Z. Khalajabadi, N. Ahmad, S. Izman, A.B.H. Abu, W. Haider, and M.R.A. Kadir, J. Alloys Compd. 696, 768 (2017).

316. T. Lei, W. Tang, S.-H. Cai, F.-F. Feng, and N.-F. Li, Corros. Sci. 54, 270 (2012).

317. M. Yu, C. George, Y. Cao, D. Wootton, and J. Zhou, J. Mater. Sci. 49, 3629 (2014).

318. H. Ye, X.Y. Liu, and H. Hong, J. Mater. Sci. Mater. Med. 20,843 (2009)

319. J. Weng, X. Liu, X. Zhang, and X. Ji, J. Mater. Sci. Lett. 13, 159 (1994).

320. T. Tähti, 3 (2004)

321. Y. Yin, Q. Huang, L. Liang, X. Hu, T. Liu, Y. Weng, T. Long, Y. Liu, Q. Li, S. Zhou, and H. Wu, J. Alloys Compd. 785,38 (2019)

322. L.-C. Zhang, and H. Attar, Adv. Eng. Mater. 18, 463 (2015).

323. P. Dhavalikar, Z. Lan, R. Kar, K. Salhadar, A. K. Gaharwar, and E. Cosgriff-Hernandez, Biomedical Applications of Additive Manufacturing, Fourth Edi (Elsevier, 2020).

324. D. Gu, Y.-C. Hagedorn, W. Meiners, K. Wissenbach, and R. Poprawe, Compos. Sci. Technol. 71, 1612 (2011).

325. S. Tjong, Mater. Sci. Eng. R Rep. 29, 49 (2000).

326. H. Attar, M. Bönisch, M. Calin, L.C. Zhang, S. Scudino, and J. Eckert, Acta Mater. 76, 13 (2014).

327. M. Harhash, A. Carrado, and H. Palkowski, in Adv. Compos. Aerospace, Mar. L. Appl. (John Wiley \& Sons, Inc., 2014), pp. 243-254.

328. I. Burchitz, R. Boesenkool, S. van der Zwaag, and M. Tassoul, Mater. Des. 26, 271 (2005).

329. E.C. Botelho, R.A. Silva, L.C. Pardini, and M.C. Rezende, Mater. Res. 9, 247 (2006).

330. K.F. Karlsson, and B. TomasÅström, Compos. Part A Appl. Sci. Manuf. 28, 97 (1997).

331. M. Ebrahimi Saravi, M. Vojdani, and F. Bahrani, J. Dent. 9, 180 (2012). 
332. M. Reggente, M. Harhash, S. Kriegel, P. Masson, J. Faerber, G. Pourroy, H. Palkowski, and A. Carradò, Compos. Struct. 218, 107 (2019).

333. M. Reggente, P. Masson, C. Dollinger, H. Palkowski, S. Zafeiratos, L. Jacomine, D. Passeri, M. Rossi, N.E. Vrana, G. Pourroy, and A. Carradò, A.C.S. Appl. Mater. Interfaces 10, 5967 (2018).
Publisher's Note Springer Nature remains neutral with regard to jurisdictional claims in published maps and institutional affiliations. 